\title{
Top-down and bottom-up regulation of phytoplankton assemblages in tidepools
}

\author{
Anna Metaxas*, Robert E. Scheibling \\ Department of Biology, Dalhousie University, Halifax, Nova Scotia, Canada B3H 4J1
}

\begin{abstract}
We examined the relative importance of bottom-up (nutrient availability) and top-down (grazing) factors in regulating phytoplankton assemblages in tidepools on a rocky shore near Halifax, Nova Scotia, Canada. We manipulated the concentration of nutrients and density of micrograzers in pools in the high intertidal and splash zones in 3 repeated, 1 to 2 wk experiments in November 1992 and June and August 1993. For each experiment, we set up 4 orthogonal treatments in enclosures in each of 3 or 4 pools: (1) micrograzers removed and nutrients enriched, (2) micrograzers removed and nutrients at natural levels, (3) micrograzers at natural densities and nutrients enriched, and (4) both micrograzers and nutrients at natural levels. For each treatment, we measured the change in abundance over $1 \mathrm{wk}$ intervals of 5 taxonomic groups of phytoplankton: centric diatoms, pennate diatoms, cryptomonads, prasinophytes, and chlorophytes. We examined the effects of nutrient concentration, grazer density, and pool on the phytoplankton assemblage using multivariate analysis of variance. There were significant effects of grazer density in June and August, and of nutrient concentration in August, which varied among phytoplankton groups and tidepools. In 1 pool in June, reduction in grazer density had a negative effect on pennate diatoms, cryptomonads and chlorophytes in the first week of the experiment, but a positive effect on pennate diatoms in the second week. In another pool in the second week, grazer reduction had a positive effect on prasinophytes but a negative effect on chlorophytes. In 1 pool in August, nutrient enrichment had a positive effect on prasinophytes in the first week of the experiment, and grazer reduction had a negative effect on cryptomonads and chlorophytes in the second week. In another pool in the first week, nutrient enrchment had a negative effect on chlorophytes. Based on the frequency of significant effects, we concluded that grazing is more important than the nutrient regime in regulating phytoplankton assemblages in tidepools. The large variability among tidepools in the response of phytoplankton to our manipulations supports our previous suggestion that regulation of these assemblages occurs at the scale of the individual pool rather than the intertidal zone.
\end{abstract}

KEY WORDS: Community regulation - Phytoplankton · Tidepools · Grazing · Nutrients · Experimental manipulations S Spatial variability Enclosures

\section{INTRODUCTION}

Plant communities often are regulated by top-down factors such as herbivory and bottom-up factors such as nutrient concentration. Top-down regulation occurs when plant community structure (species composition and abundance) depends upon activities at higher trophic levels, whereas bottom-up regulation occurs

- Address for correspondence: Department of Larval Ecology, Harbor Branch Oceanographic Institution, 5600 U.S. 1 North, Fort Pierce, Florida 34946, USA

E-mail:metaxas@hboi.edu when the structure depends upon resource availability. The importance of top-down and bottom-up factors in community regulation has been studied most extensively in lake systems (see Kerfoot \& Sih 1987 for reviews). Some experimental and modelling studies have shown that top-down factors are most important in determining algal biomass, concentration of chlorophyll $a$, and phytoplankton size-distribution, either directly through grazing or indirectly through increased nutrient supply by excretion (e.g. Lynch \& Shapiro 1981, Carpenter \& Kitchell 1984, Vanni \& Findlay 1990, Hansson 1992). Other studies have shown that zooplankton grazing is not important in 
regulating phytoplankton biomass (e.g. Threlkeld 1988, McQueen et al. 1989) but rather that concentration of chlorophyll $a$ is directly related to nutrient concentration (e.g. McQueen et al. 1989, Hansson 1992). Lynch \& Shapiro (1981) showed that nutrient enrichment can result in shifts in numerical dominance of phytoplankton species. In an empirical model of topdown and bottom-up forcing on the trophic structure of oligotrophic and eutrophic lakes. McQueen et al. (1986) showed that phytoplankton production is determined primarily by nutrients and that the effect of herbivores is dependent on herbivore size. It is becoming increasingly evident that the relative importance of top-down and bottom-up regulation of primary producers in a given community probably varies with season, the structure of the food-web, and phytoplankton and grazer species composition (e.g. Vanni 1987. Vanni \& Temte 1990, Hansson 1992). Hunter \& Price (1992) provided a model of top-down and bottom-up community regulation which incorporated the inherent heterogeneity in natural systems.

In marine systems, the importance of nutrients and grazers in regulating phytoplankton abundance and community structure is well documented (see Harrison et al. 1983, Hecky \& Kilham 1988, Reid et al. 1990, Gervais 1991, Morales et al. 1991, Wassman 1991 for reviews). However, the relative importance of these 2 factors still remains unclear, mainly because of the difficulty in conducting experimental manipulations in the ocean. Recently, Kivi et al. (1993) manipulated the nutrient regime and abundance of grazers in factorial experiments in enclosures in the Baltic Sea and found that the relative importance of bottom-up and topdown regulation of the phytoplankton assemblages varied with season.

Community organization of rocky intertidal shores has been studied extensively, and the importance of top-down regulating factors is well established (e.g Paine 1966, Dayton 1971, 1984, Connell 1972, 1983. Menge 1976, Lubchenco \& Menge 1978, Petraitis 1983, 1987, Sousa 1984, Underwood \& Denley 1984, Jernakoff 1985). Filter-feeders such as mussels and barnacles are often the dominant space occupiers on these shores. One of their food sources is phytoplankton, the abundance and species composition of which can be greatly affected by nutrient concentration. However, the effect of nutrient availability in the regulation of rocky intertidal communities remains largely unknown. Menge (1992) suggested that this gap in our knowledge is partly the result of the difficulty in experimentally manipulating the concentrations of nutrients in these systems. On shores with colonies of seabirds, guano can be a source of increased nutrients (Ganning \& Wulff 1969, Bosman \& Hockey 1986) and a few descriptive studies have suggested that the supply of guano may affect the abundance and community composition of macroalgae (Bosman \& Hockey 1986, 1988, Wootton 1991). In an unreplicated experiment, Bosman et al. (1986) observed an increase in chlorophyll a of benthic microalgae when they increased the supply of guano to the high intertidal zone of a rocky shore in South Africa.

In a previous study, we found that phytoplankton assemblages of tidepools do not show zonation along the intertidal gradient, but vary greatly among pools within intertidal zones in relation to the particular physical characteristics and biological processes within each pool (Metaxas \& Scheibling 1996). In this study, we examine the relative effects of bottom-up and top-down factors on the composition and abundance of phytoplankton assemblages in tidepools on a rocky intertidal shore. Tidepools facilitate the study of these processes because (1) they provide a habitat for plankton during the entire tidal cycle, (2) they have well-defined boundaries, and (3) they are of manageable size to carry out manipulations. We manipulated the concentration of nutrients and the density of micrograzers in factorial experiments in tidepools. To our knowledge, this is the first study to examine experimentally the relative importance of bottom-up and topdown factors in regulating the assemblages of primary producers on rocky intertidal shores.

\section{MATERIALS AND METHODS}

Study site and biological assemblage. In a previous study (Metaxas \& Scheibling 1996), we examined sources of variability in the spatial distribution of phytoplankton assemblages, and the biotic (planktonic and benthic grazers) and abiotic (nutrients, temperature, salinity, and $\mathrm{pH}$ ) factors that regulate these assemblages, in tidepools on a rocky shore at Cranberry Cove, near Halifax, Nova Scotia, Canada $\left(44^{\circ}\right.$ $28^{\prime} \mathrm{N}, 63^{\circ} 56^{\prime} \mathrm{W}$ ), between March 1991 and November 1992 . The site consists of granitic platforms with a 10 to $30 \%$ grade and has a southern exposure to oceanic swells which reach wave heights of up to $10 \mathrm{~m}$ during autumn storms. The tidepools (maximum dimension 2 to $14 \mathrm{~m}$, depth 0.13 to $0.64 \mathrm{~m}$ ) were located across the intertidal gradient, with 4 pools in each of the mid (isolation period per tidal cycle $6 \pm 2 \mathrm{~h}$, mean $\pm \mathrm{SD}$ ), high $(11 \pm 1 \mathrm{~h})$ and splash ( $>12 \mathrm{~h}$ tidal cycle, up to $2 \mathrm{mo}$ ) zones. Flushing rate (volume of water exchanged over half a tidal cycle) ranged from 78 to $86 \%$ for mid pools, 32 to $36 \%$ for high pools and 6 to $31 \%$ for splash pools, depending on weather conditions.

Pennate diatoms (mainly Amphriprora spp., Cylindrotheca closterium, Licmophora spp. and Nitzschia spp.), cryptomonads (mainly Cryptomonas sp.) and 
chlorophytes (mainly Dunaliella tertiolecta) were the dominant phytoplankton in the pools throughout the

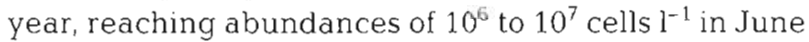
and July and decreasing to $10^{3}$ to $10^{5}$ cells $l^{-1}$ between October and April (Metaxas \& Scheibling 1996). Centric diatoms were introduced into pools during the spring and fall blooms in the surrounding seawater (Chaetoceros spp. and Skeletonema costatum, in spring, and Rhizosolenia spp. in fall), reaching abundances of $10^{5}$ to $10^{6}$ cells $l^{-1}$, but were absent from pools during the rest of the year. There was little indication of vertical zonation of the phytoplankton assemblages along the intertidal gradient: differences among intertidal zones rarely explained more than $30 \%$ of the spatial variability in phytoplankton abundance. However, all groups of phytoplankton varied significantly among pools within intertidal zones throughout the year, and differences among pools explained up to $96 \%$ of the variability in phytoplankton abundance.

Micrograzers (motile invertebrates retained by a $60 \mu \mathrm{m}$ sieve) were grouped as benthic and planktonic according to their functional morphology and mode of feeding (Metaxas \& Scheibling 1996). The major groups of planktonic micrograzers were calanoid copepodites and nauplii (the genera Acartia, Calanus, Paracalanus, Pseudocalanus and Temora in mid pools, and Eurytemora affinis in splash pools), marine cladocerans (Podon polyphemoides and Evadne nordmanii) and marine rotifers (the genera Brachionus and Synchaeta) (Metaxas \& Scheibling 1994a). The major groups of benthic micrograzers included harpacticoid copepodites and nauplii (Families Harpacticidae, Tisbidae, Thalestridae and Diosaccidae), foraminiferans and nematodes. The abundance of calanoid copepods, rotifers, harpacticoid copepods and nematodes increased in summer, mainly in high and splash pools $\left(10^{6}\right.$ to $10^{7}$ ind. $\left.\mathrm{m}^{-3}\right)$. Cladocerans and foraminiferans were rare to absent in tidepools for most of the year but showed pulses in abundance $\left(10^{4}\right.$ to $10^{5}$ ind. $\left.\mathrm{m}^{-3}\right)$ in some high and splash pools in late summer and fall. As with phytoplankton, planktonic and benthic micrograzers did not show zonation in abundance along the intertidal gradient but varied significantly among pools within zones. This amongpool variability was the result of large, singletaxon populations of micrograzers that were established in individual high and splash pools and persisted interannually.

The concentration of macronutrients increased from spring to summer and decreased in fall in high and splash pools (nitrate+nitrite and phosphate 0.1 to $10 \mu \mathrm{M}$, ammonium 0 to $5 \mu \mathrm{M}$, silicate 1 to $30 \mu \mathrm{M}$ ) (Metaxas \& Scheibling $1994 \mathrm{~b}, 1996)$. The concentration of macronutrients also showed little variation along the inter- tidal gradient but was highly variable among pools within zones throughout the year

Multiple regression analysis indicated that the phytoplankton assemblage in these tidepools was primarily regulated by the nutrient regime and the grazer field (rather than the physical characteristics of pools), and that these factors operated more at the scale of the individual pool than the intertidal zone.

Experimental design. To examine the effects of nutrient addition and grazer removal on the phytoplankton assemblages, we repeated the same experiment in 3 different months in enclosures in tidepools in the high and splash zones at Cranberry Cove. We used pools in these zones because they had sufficiently long isolation periods and low flushing rates to enable us to determine experimental effects on resident phytoplankton assemblages (see 'Study site and biological assemblage'). The physical characteristics of the 5 pools used in this study, a subset of those described in Metaxas \& Scheibling (1996), are summarized in Table 1 . We conducted the first experiment between 15 and 21 November 1992 in 4 pools (Pools 1, 3, 4 and 5), the second between 20 June and 3 July 1993 in 3 pools (Pools 1, 3 and 5), and the third between 1 and 15 August 1993 in 4 pools (Pools 1, 2, 3 and 5). The lower number of pools used in June was because of losses of experimental enclosures during storms. We set up 4 experimental treatments in each pool in a factorial design: (1) grazers removed and nutrients enriched ( $\mathrm{G}-\mathrm{N}+$ ); (2) grazers removed and nutrients at natural levels ( $\mathrm{G}-\mathrm{No}$ ); (3) grazers at natural densities and nutrients enriched (GoN+); and (4) both grazers and nutrients at natural levels (GoNo). We used the water column outside enclosures as a natural control to examine the artifactual effect of enclosures on the phytoplankton assemblages, as well as treatment efficacy. We used 2 replicates per treatment or natural control in November, and we used 3 replicates in June and August. We randomly allocated all treatments to replicate enclosures; we selected random locations within a pool as natural controls.

Table 1 Physical characteristics of 5 tudepools used in the experiments at Cranberry Cove, Nova Scotia, Canada. Pools 1 and 2 are located in the high intertidal zone and Pools 3,4 and 5 are located in the splash zone. (c.d.) chart datum; (-) no input during $12 \mathrm{~h}$ tidal cycle

\begin{tabular}{|cccccc|}
\hline $\begin{array}{c}\text { Pool } \\
\text { Surface }\left(\mathrm{m}^{2}\right)\end{array}$ & $\begin{array}{c}\text { Maximum } \\
\text { depth }(\mathrm{m})\end{array}$ & $\begin{array}{c}\text { Volume } \\
\left(\mathrm{m}^{3}\right)\end{array}$ & $\begin{array}{c}\text { Isolation } \\
\text { period (h) }\end{array}$ & $\begin{array}{c}\text { Height } \\
\text { above c.d. }(\mathrm{m})\end{array}$ \\
\hline 1 & 24.23 & 0.641 & 7.28 & 12 & 2.6 \\
2 & 11.84 & 0.134 & 0.68 & 10 & 2.9 \\
3 & 8.85 & 0.308 & 1.15 & - & 3.4 \\
4 & 7.47 & 0.320 & 0.71 & - & 3.9 \\
5 & 3.94 & 0.425 & 0.94 & - & 4.5 \\
\hline
\end{tabular}


The enclosures were made of clear acrylic pipe $12 \mathrm{~cm}$ in inmer diameter (12.7 cm outer diameter) and $12 \mathrm{~cm}$ in height. These enclosures were set into bases made of $3 \mathrm{~cm}$ high rings of plastic sewer pipe $(13 \mathrm{~cm}$ inner diameter) cemented to the rock bottom of the pools with an epoxy putty (A-788 Splash Zone Compound, Z-SPAR, Koppers Company Inc., Los Angeles, CA) We affixed a ring of closed-cell polyethylene foam to the bottom end of the acrylic pipe with silicone glue to provide an ' 0 '-ring seal between the enclosure and the base. We lowered the enclosures slowly into the cemented bases to minimize disturbance of the water column, and firmly attached them with cable ties. The top of each enclosure was loosely covered (to allow gas-exchange) with a clear plastic sheet attached with elastic bands. The bottom of the enclosure was the undisturbed natural substratum. Each enclosure was positioned at $8 \mathrm{~cm}$ depth in the pools, contained $1 \mathrm{l}$ of seawater and did not receive any input during the experimental period. Incident light, measured at mid depth in the water column using a Biospherical Instruments Inc. (San Diego, CA) QSL-100 light meter, was $1295 \pm 764$ (mean $\pm \mathrm{SD}, \mathrm{n}=2$ ) inside and $1411 \pm$ $349 \mu \mathrm{mol} \mathrm{m} \mathrm{m}^{-2} \mathrm{~s}^{-1}$ outside the enclosures.

We set up the treatments once the enclosures were in place. We removed both planktonic and benthic micrograzers by hand-pumping the seawater from the enclosure through a $60 \mu \mathrm{m}$ net. We visually inspected the sides and bottom of the enclosures and removed adherent micrograzers. We then poured the filtered water back into the enclosure. We enriched nutrients (silicate, phosphate and nitrate) by adding small volumes (1 to $2 \mathrm{ml}$ ) of nutrient stocks $\left(\mathrm{Na}_{2} \mathrm{SiO}_{3} \cdot 9 \mathrm{H}_{2} \mathrm{O}\right.$, $\mathrm{Na}_{2}$ glyceroPO $\mathrm{P}_{4}$, and $\mathrm{NaNO}_{3}$ ) to match the nutrient levels in a widely-used growth-medium (ES) for phytoplankton culturing (Harrison et al. 1980). These nutrient levels allow non-limited growth of phytoplankton for 7 to $10 \mathrm{~d}$ (approximately the duration of our experiments) in batch cultures (such as the enclosures) (Harrison et al. 1980) We stirred the water in the enclosures to ensure initial homogeneous mixing of nutrients. We collected a $60 \mathrm{ml}$ sample of seawater from each enclosure and control location at the beginning (immediately after the treatments were set up) and end of each experiment with an acid-washed ( $1 \mathrm{~N}$ $\mathrm{HCl}$ ) polypropylene syringe. We filtered these samples through $0.80 \mu \mathrm{m}$ Millipore ${ }^{\otimes}$ filters into acid-washed polypropylene containers in the field and froze them for subsequent nutrient analysis. We measured nitrate+nitrite, silicate and phosphate concentrations in each sample using a Technicon AA2 autoanalyzer. We determined ammonium concentration according to Parsons et al. (1984) on a Jenway 6100 spectrophotometer At the end of each experiment, after all sampling was completed, we collected the micrograzers from each enclosure by hand-pumping all of the seawater through a $60 \mu \mathrm{m}$ net and manually removing any adherent micrograzers from the sides and bottom of the enclosures. We rinsed the contents of the net into containers and fixed the samples with $4 \%$ buffered formaldehyde. Similarly, we collected 1 I samples at each of the control locations in the pools to determine natural densities of micrograzers. We enumerated micrograzers using a Leitz Labovert inverted microscope and identified them according to Smith (1964), Brinkhurst et al. (1976), Barnes (1980) and Gardner \& Szabo (1982).

We collected a $20 \mathrm{ml}$ sample of phytoplankton with a polypropylene syringe at mid depth within each enclosure and from control locations. We collected phytoplankton samples at the beginning and the end of each experiment on all dates, as well as at the mid points (i.e. after 7 d) of the experiments in June and August. We placed the phytoplankton samples in a plastic container and rinsed the syringe into the same container with $20 \mathrm{ml}$ of distilled water. We preserved the samples in Lugol's solution and stored them in the dark for subsequent enumeration. Before counting, we inverted the phytoplankton samples 50 times and we allowed subsamples to settle overnight in $25 \mathrm{ml}$ settling chambers (Lund et al. 1958). We enumerated phytoplankton using a Leitz Labovert inverted microscope and identified them according to Cupp (1943), Hendey (1964), Sournia (1986), Ricard (1987) and Chrétiennot-Dinet (1990).

Statistical analyses. We examined the effect of enclosures on the density of micrograzers at the end of each experiment, and on the concentration of nutrients at the beginning and end of each experiment, using 2 -factor analyses of variance with Treatment (natural control, unmanipulated enclosure) as a fixed factor and Pool as a random factor. To assess the possibility of an increase in the concentration of nutrients in the watercolumn of the pools over the experimental period due to leakage of the enclosures, we examined changes in the concentration of nutrients in the natural controls over the same period using 2-factor analyses of variance with Time (beginning, end) as a fixed factor and Pool as a random factor. For both of these analyses, we tested the effects of the main factors Treatment and Time against the residual mean square error when the interaction terms that included the random factor (Treatment $\times$ Pool, Time $\times$ Pool) were not significant at $\alpha=0.250$.

To test the efficacy of our treatment manipulations, we examined differences among treatments in the density of micrograzers at the end of each experiment, and in the concentration of nutrients at the beginning and end of each experiment, using 3-factor analyses of variance with 2 fixed factors, Grazer Density (natural, reduced) and Nutrient Concentration (natural, 
enriched), and 1 random factor, Pool ( 3 or 4 pools depending on date). We tested the main effects and the interaction terms of the fixed factors (Grazer Density, Nutrient Concentration, Grazer Density $\times$ Nutrient Concentration) against the residual mean square error when the interaction terms that included the random factor (Grazer Density $\times$ Pool, Nutrient Concentration $x$ Pool and Grazer Density $x$ Nutrient Concentration $x$ Pool) were not significant (Underwood 1981) at $\alpha=$ 0.250 ; otherwise we tested them against the mean square error of the appropriate interaction term. For the analyses, micrograzers were grouped separately as benthic and planktonic according to their functional morphology and mode of feeding (see Metaxas \& Scheibling 1994a, 1996).

For statistical analyses, phytoplankton were assigned to 5 taxonomic groups: centric diatoms, pennate diatoms, cryptomonads, prasinophytes and chlorophytes. Because of large variability in phytoplankton abundance among pools (see Metaxas \& Scheibling 1996) we examined differences among treatments in the change in abundance of each group, calculated as In (final abundance/initial abundance). We calculated change in abundance separately for the first and second weeks of the experiments. For each sampling time, we examined differences in change in abundance of the phytoplankton assemblage using 3-factor multivariate analysis of variance (MANOVA) with Grazer Density (natural, reduced), Nutrient Concentration (natural, enriched), and Pool ( 3 or 4 pools depending on date) as fixed factors. When there was a significant 2-way interaction with the factor Pool (Nutrient Concentration $\times$ Pool and Grazer Density $\times$ Pool), we did 1-factor MANOVA within each Pool. If there was a significant effect of Grazer Density or Nutrient Concentration, we did 1-factor ANOVA for each phytoplankton group within that Pool. We also examined the effect of enclosures on change in the abundance of the phytoplankton assemblage using 2-factor MANOVA with Treatment (natural control, unmanipulated enclosure) and Pool ( 3 or 4 pools depending on date) as fixed factors and proceeding in the same sequence as above. We fixed the factor Pool, because the large number of dependent variables relative to the number of observations provided too few degrees of freedom for a mixed model MANOVA. However, in all cases we detected significant interactions with the factor Pool which led us to do separate MANOVAs for each Pool. Therefore, the assignment of Pool as a fixed (rather than random) factor is inconsequential to the overall analysis because the tests of the main factors Grazer Density and Nutrient Concentration were never relevant in the 3-factor MANOVA.

For all statistical analyses, nutrient concentration and grazer density were $\ln (x+1)$-transformed to re- move heterogeneity of variance, as detected using Cochran's test $(p<0.05)$. Although the original experimental design was orthogonal and balanced, we lost some replicate enclosures during the experiments in June and August. To maximize degrees of freedom at the expense of an unbalanced design, we carried out least-squares ANOVA and a posteriori comparisons (using Student-Newman-Keuls tests) of arithmetic means for treatments with equal sample sizes and of harmonic means for treatments with unequal sample sizes (Winer 1971). The null hypothesis was rejected at $p<0.05$ for all statistical tests.

\section{RESULTS}

\section{Experimental manipulations}

\section{Experimental artifacts}

We detected artifactual effects of our experimental enclosures on the change in abundance of phytoplankton in August, but only during the first week of the experiment (Table 2). At this time, prasinophytes in 1 pool (Pool 2) increased in the procedural control (GoNo treatment) but did not change significantly in abundance in the natural control. Also, chlorophytes in 2 pools (Pools 1 and 2) increased in the procedural control and decreased in the natural control, while cryptomonads in another pool (Pool 5) showed the opposite trend. There were no artifactual effects in the experiments in November and June.

We also detected artifactual effects of our enclosures on the density of micrograzers and/or the concentration of nutrients in each of our experiments (Figs. 1 \& 2). The density of benthic micrograzers was greater in the procedural control than in the natural control in all pools in November (Table 3 ). Conversely, the density of planktonic micrograzers was less in the procedural control than in the natural control in June and August, but only in some pools (Table 3). There were some significant differences in the concentration of manipulated nutrients between natural and procedural controls, but these were not consistent among nutrients or between the beginning and end of experimental periods (Table 4). In June and August, the concentration of ammonium, which was not manipulated, was greater in the procedural than in the natural control in 2 pools (Pools 3 and 5) at the end of the experiment.

The concentrations of manipulated nutrients in the natural controls varied little over the experimental periods. We detected significant interactions between Time and Pool for silicate and phosphate in June (silicate $F_{2,12}$ $=12.78, \mathrm{p}=0.001$; phosphate $F_{2,12}=118.1, \mathrm{p}<0.001$ ) and August (silicate $F_{3,16}=5.80, \mathrm{p}<0.01$; phosphate $F_{3,16}=$ 
Table 2. F-values of significant multivariate (MANOVA, Wilk's $\lambda$ ) and univariate (ANOVA) analyses of varance of percentage change in abundance of different phytoplankton groups (Ce: centric diatoms; Pe: pennate diatoms; $\mathrm{Cr}$ : cryptomonads; Pr: prasinophytes; Ch: chlorophytes) between procedural controls (GoNo) and natural controls (C) in the experiments in November 1992 and June and August 1993. The first line for each period for each date shows the results of MANOVA followed by results of ANOV $\mathrm{A}$ for each phytoplankton group. Where there was a significant Treatment $\times$ Pool interaction in the MANOVA, results of A $、$ OVA are given for edch phytoplankton group for each Pool. Comparisons show the direction of significant difference. Degrees of freedom are shown in parentheses. For significant $F$-values $(p<0.05): \cdots p<0.001, \cdots p<0.01, " p<0.05$

\begin{tabular}{|c|c|c|c|c|c|c|c|}
\hline Date & Period (d) & Pool & Group & Treatment & $\begin{array}{l}\text { Factor } \\
\text { Pool }\end{array}$ & Treatment $\times$ Pool & Comparison \\
\hline Nov 1992 & $1-7$ & All & All & $0.43_{(4,5)}$ & $3.05^{\circ}$ & $2.27,12,13\}$ & \\
\hline Jun 1993 & $\begin{array}{l}1-7 \\
8-14\end{array}$ & $\begin{array}{l}\text { All } \\
\text { All }\end{array}$ & $\begin{array}{l}\text { All } \\
\text { All }\end{array}$ & $\begin{array}{l}1.05_{\{4,8 !} \\
0.67_{\mid 4,8\}}\end{array}$ & $\begin{array}{l}5.53 \cdots \\
4.71{ }^{(8.16)}\end{array}$ & $\begin{array}{l}2.40_{\{8.16 !} \\
1.23_{|8,16|}\end{array}$ & \\
\hline Aug 1993 & $1-7$ & $\begin{array}{c}\text { All } \\
1 \\
2 \\
2 \\
5\end{array}$ & $\begin{array}{l}\mathrm{All} \\
\mathrm{Ch} \\
\mathrm{Pr} \\
\mathrm{Ch} \\
\mathrm{Cr}\end{array}$ & $\begin{array}{r}9.81 \cdots \\
112.7 \cdots \\
380.8 \cdots{ }_{(1,4)}^{(1,4)} \\
7.92{ }_{(1,4)} \\
25.45 \cdots_{(1,4)}\end{array}$ & $5.97 \cdots_{i 12,34 !}$ & $4.72 \cdots_{112.34 !}$ & $\begin{array}{l}\text { GoNo }>\mathrm{C} \\
\text { GONO }>\mathrm{C} \\
\text { GONO }>\mathrm{C} \\
\text { GONO }<\mathrm{C}\end{array}$ \\
\hline & $8-14$ & All & All & $2.83_{(4,13)}$ & $0.88_{(12.34)}$ & $0.93_{(12.341}$ & \\
\hline
\end{tabular}

Table 3. F-values of significant analyses of vanance of the density of micrograzers between procedural controls (GoNol and natural controls (C) at the end of the experiments in November 1992, and June and August 1993. Comparisons show the direction of significant difference. Degrees of freedom are: November 1992: $F_{\text {Treatment } \text { Pool, }} F_{\text {Pool }}=3,8$; if $\mathrm{p}_{F \text { Treatment } \times \text { Pool }}>0.250, F_{\text {Treatment }}=1,8$; if $\mathrm{p}_{\text {FTreament } \times \text { Pool }}<0.250, F_{\text {Treatment }}=1,3$; June 1993: $F_{\text {Treatment poolt }} F_{\text {Pool }}=2,9$; if $\mathrm{p}_{F \text { Treatment Pool }}>0.250, F_{\text {Ttealment }}=1,9$; If $\mathrm{p}_{F_{\text {Treatment } \times \text { Pool }}}<0.250, F_{\text {Treatmen }}=1,2 ;$ August 1993: $F_{\text {Treatment } \times \text { Pool, }} F_{\text {Pool }}=3,14 ;$ if $p_{F \text { Treattriant } \times \text { Pool }}>0.250, F_{\text {Treatment }}=1,14$;

\begin{tabular}{|c|c|c|c|c|c|}
\hline Date & Group & Trcatment $\times$ Pool & Pool & Treatment & Comparison \\
\hline Nov 1992 & Benthic & 0.28 & 3.64 & $10.92^{\circ}$ & GoNo $>C$ \\
\hline Jun 1993 & Planktonic & $6.02^{\bullet}$ & $12.45^{\cdots}$ & $0.75^{\mathrm{a}}$ & Pool 1: GoNo $<$ C \\
\hline Aug 1993 & Planktonic & $25.98 \cdots$ & $70.45 \cdots$ & $0.91^{\mathrm{d}}$ & Pools 2, 3: GoNo $<\mathrm{C}$ \\
\hline
\end{tabular}

Table 4. F-values of significant analyses of variance of the concentrations of nutrients between procedural controls (GoNo) and natural controls (C) at the beginning (Beg) or end of the experiments in November 1992 and June and August 1993. Comparisons show the results of Student-Newman-Keuls comparisons of treatment means. Degrees of freedom are: November 1992

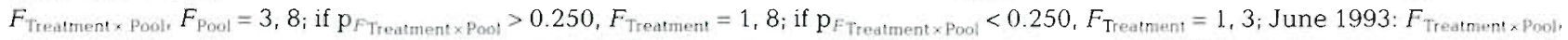
$F_{\text {Pool }}=2,9 ;$ if $p_{F \text { Treatment } \times \text { Pool }}>0.250, F_{\text {Treatment }}=1,9 ;$ if $p_{\text {FTreatment } \times \text { Pool }}<0.250, F_{\text {Treatment }}=1,2 ;$ August 1993: $F_{\text {Treatrment } \times \text { Pool }}, F_{\text {Poal }}=3,14 ;$ if $\mathrm{p}_{F_{\text {Treatment } \times \text { Pool }}}>0.250, F_{\text {Treatment }}=1,14$; if $\mathrm{p}_{F_{\text {Treatment }} \text { Pooi }}<0.250, F_{\text {Treatment }}=1,3$. For significant $F$-values $(\mathrm{p}<0.05): \cdots p<0.001$; $\because p<0.01 ; \cdot p<0.05$

\begin{tabular}{|c|c|c|c|c|c|c|}
\hline Date & Nutrient & Time & Treatment $\times$ Pool & Pool & Treatment & Comparison \\
\hline Nov 1992 & Silicate & Beg & 1.04 & 2.31 & $6.36^{\circ}$ & GoNo $>$ C \\
\hline \multirow[t]{3}{*}{ Jun 1993} & Silicate & Beg & $5.37^{\circ}$ & $41.08 \cdots$ & $0.14^{\mathrm{d}}$ & $\begin{array}{l}\text { Pool 3: GoNo }>\text { C } \\
\text { Pool 5: GoNo }<\mathrm{C}\end{array}$ \\
\hline & & End & $6.56^{\circ}$ & $6.40^{\circ}$ & $0.80^{\star}$ & Pool 3: GoNo $<\mathrm{C}$ \\
\hline & Ammonium & End & $7.86^{\circ}$ & $12.09 \cdots$ & $5.57^{\mathrm{a}}$ & Pools 3, 5: GoNo $>C$ \\
\hline \multirow[t]{4}{*}{ Aug 1993} & Silicate & End & $6.14^{\cdot}$ & $13.49^{\circ}$ & $0.57^{i}$ & $\begin{array}{l}\text { Pool 1. GoNo }>\mathrm{C} \\
\text { Pools 2, 5: GoNo }<\mathrm{C}\end{array}$ \\
\hline & Phosphate & Beg & $3.50^{\circ}$ & $101.8 \cdots$ & $0.60^{\mathrm{d}}$ & $\begin{array}{l}\text { Pool 1. GoNo }>C \\
\text { Pool 2: GoNo }<C\end{array}$ \\
\hline & Phosphate & End & 1.51 & 2.19 & $5.96^{\circ}$ & GoNo $>C$ \\
\hline & Ammonium & End & $5.79^{\circ}$ & $8.89^{\circ}$ & $6.01^{\circ}$ & Pools 3, 5: GoNo $>C$ \\
\hline
\end{tabular}


$6.14, \mathrm{p}<0.01)$. The concentration of both of these nutrients decreased between the beginning and the end of the experiments, but not in all pools. In November, we did not detect a significant change in concentration for any manipulated nutrient (in all cases $F_{1,8}<5.32, \mathrm{p}>0.05$ )

\section{Efficacy of experimental manipulations}

In November, there were few reductions in the mean densities of planktonic and benthic micrograzers in the grazer removal treatments $\left(\mathrm{G}-=\right.$ pooled $\mathrm{G}-\mathrm{N}_{0}$ and $\left.\mathrm{G}-\mathrm{N}+\right)$ relative to treatments where grazers were not manipulated $(\mathrm{Go}=$ pooled GoNo and GoN+). We attribute the lack of a manipulation effect to the low natural densities of both groups of grazers in the pools at that time (Fig. 1, Table 5). However, in June and August, when micrograzers were more abundant, the mean densities of both groups were lower in the grazer removal treatments in most pools. A notable exception was Pool 3 in June, where mean densities of micrograzers were greater in the grazer removal treatments than in treatments where grazers were not manipulated. Marine waterboatmen (corixids) were abundant in this pool but they were removed in our manipulated treatments. These corixids are carnivorous and probably consumed more micrograzers in the treatments where grazers were not manipulated, resulting in lower grazer densities in these treatments than in the grazer removal treatments. In August, we manually removed corixids from all treatments in this pool.

Despite the observed reductions in planktonic and/or benthic micrograzers in most grazer removal treatments, few of these were statistically significant (Table 6). However, large among-pool variability in grazer density required us to test the effect of grazers against the interaction term, Grazer Density $\times$ Pool, resulting in low error degrees of freedom and low statistical power.

At the beginning of all experiments, the concentrations of silicate and nitrate+nitrite were 1 to 2 orders of magnitude greater in the nutrient-enriched treatments $\left(\mathrm{N}_{+}=\right.$pooled $\mathrm{GoN}+$ and $\mathrm{G}-\mathrm{N}+$ ) than in treatments where nutrients were not manipulated (No $=$ pooled GoNo and $\mathrm{G}-\mathrm{No}$ ) (Fig. 2, Table 7). The concentration of phosphate was 2 to 5 times greater in the nutrient-enriched treatments in June and August, but did not differ significantly between the nutrient-enriched and unmanipulated
NOVEMBER 1992

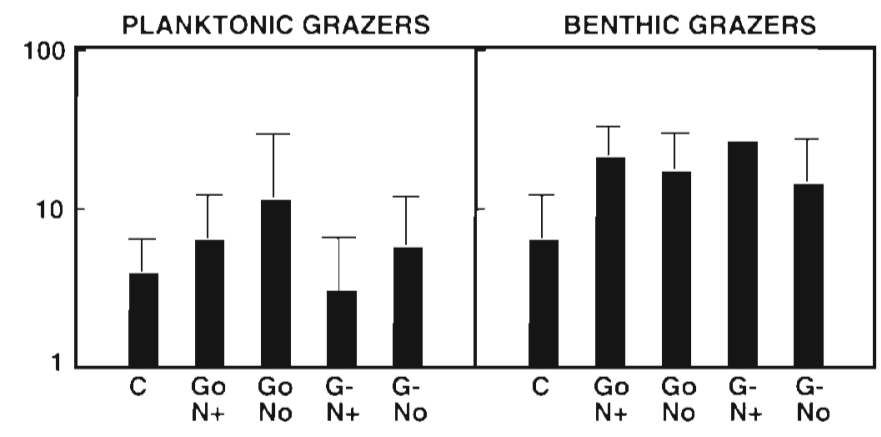

JUNE 1993

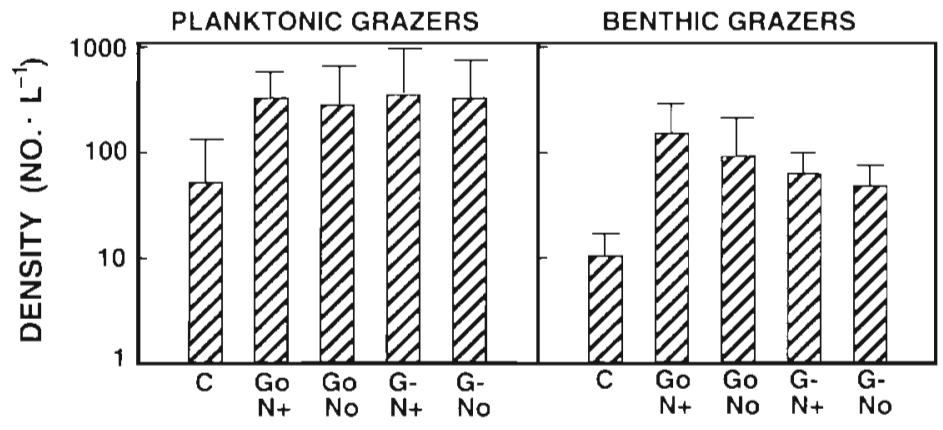

AUGUST 1993

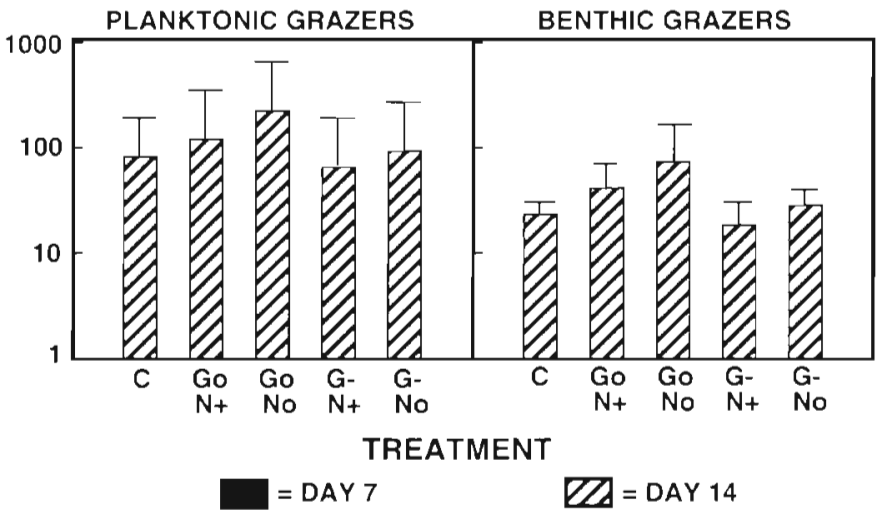

Fig. 1. Mean density of micrograzers at the end of the experiments in November 1992 and in June and August 1993 in the different treatments. C: natural controls; GoNt: treatments with natural density of grazers and enriched concentration of nutrients; GoNo treatments with natural density of grazers and natural concentration of nutrients; $\mathrm{G}-\mathrm{N}+$ : treatments with reduced density of grazers and enriched concentration of nutrients; $G-$ No: treatments with reduced density of grazers and natural concentration of nutrients Error bars represent standard deviations (November and August $\mathrm{n}=4 ;$ June: $\mathrm{n}=3$ )

treatments in November. Differences between nutrient treatments were maintained until the end of the experiment for silicate and nitrate+nitrite in most pools in November and August, and for phosphate in 1 pool in June. 
Table 5. Mean density \pm SE ( $\mathrm{n}$ is given in brackets) of micrograzers (ind. $1^{-1}$ ) in the treatments where grazers were not manipulated $\left(G_{0}=\right.$ pooled Golvo and GoN-) and in the grazer removal treatments $\left(\mathrm{G}-=\right.$ pooled $\mathrm{G}-\mathrm{No}_{\mathrm{O}}$ and $\mathrm{G}-\mathrm{N}-\mathrm{f}$ in different pools in experiments in November 1992 and in June and August 1993. In pools where there was no overlap in the standard errors of the mean densities between Go and $\mathrm{G}-$, the percentage reduction (or increase in the case of Pool 3 in June) in the $\mathrm{G}$-treatment relative to the Go is given

\begin{tabular}{|c|c|c|c|c|c|}
\hline Date & Pool & Micrograzers & Go & $\mathrm{G}-$ & Reduction (\%) \\
\hline \multirow[t]{8}{*}{ Nov 1992} & 1 & Planktonic & $23 \pm 13(4)$ & $5 \pm 4(4)$ & 76 \\
\hline & & Benthic & $14 \pm 4(4)$ & $16 \pm 6(4)$ & - \\
\hline & 3 & Planktonic & $10 \pm 3(4)$ & $11 \pm 2(4)$ & - \\
\hline & & Benthic & $25 \pm 3(4)$ & $13 \pm 2(4)$ & 47 \\
\hline & 4 & Planktonic & $2 \pm 1(4)$ & $1 \pm 0.4(4)$ & - \\
\hline & & Benthic & $9 \pm 1(4)$ & $5 \pm 2(4)$ & 44 \\
\hline & 5 & Planktonic & $2 \pm 1(4)$ & $1 \pm 0.5(4)$ & - \\
\hline & & Benthic & $33 \pm 5(4)$ & $51 \pm 10(4)$ & - \\
\hline \multirow[t]{6}{*}{ Jun 1993} & 1 & Planktonic & $627 \pm 373\{6\}$ & $123 \pm 98(6)$ & 80 \\
\hline & & Benthic & $260 \pm 89(6)$ & $89 \pm 23(6)$ & 66 \\
\hline & 3 & Planktonic & $297 \pm 70(5)$ & $890 \pm 281(5)$ & $300^{\circ}$ \\
\hline & & Benthic & $23 \pm 10(5)$ & $30 \pm 12(5)$ & - \\
\hline & 5 & Planktonic & $33 \pm 22(5)$ & $2 \pm 1(4)$ & 95 \\
\hline & & Benthic & $77 \pm 19(5)$ & $41 \pm 8(4)$ & 54 \\
\hline \multirow[t]{8}{*}{ Aug 1993} & 1 & Planktonic & $0 \pm 0(6)$ & $2 \pm 1(4)$ & - \\
\hline & & Benthic & $35 \pm 7(6)$ & $19 \pm 6(4)$ & 47 \\
\hline & 2 & Planktonic & $15 \pm 4(6)$ & $10 \pm 2(6)$ & - \\
\hline & & Benthic & $142 \pm 68(6)$ & $20 \pm 9(6)$ & 86 \\
\hline & 3 & Planktonic & $33 \pm 1.4(4)$ & $11 \pm 7(4)$ & 66 \\
\hline & & Benthic & $8 \pm 3(4)$ & $16 \pm 6(4)$ & - \\
\hline & 5 & Planktonic & $598 \pm 191(5)$ & $291 \pm 107(4)$ & 51 \\
\hline & & Benthic & $41 \pm 13(5)$ & $38 \pm 11(4)$ & \\
\hline
\end{tabular}

Effects of grazer density and nutrient concentration on the abundance of phytoplankton

The effects of grazer density and nutrient concentration on the phytoplankton assemblage varied among experiments, between weeks within experiments, and among pools. In November, when pennate diatoms and chlorophytes dominated the phytoplankton in the pools (Fig. 3), there were no significant effects of either grazer density or nutrient concentration on the assemblage (MANOVA $F_{\mathrm{G} \mid 4,13\}}=1.32, F_{\mathrm{N}|4,13|}=1.24, F_{\mathrm{G} \times \mathrm{N} \mid 4,13\}}=$ $0.66, F_{P|12,34|}=2.04, F_{G \times P|12,34|}=0.54$, $F_{\mathrm{N} \times P \mid 12,34]}=1.14, F_{G \times N \times P\{12,34\}}=0.37 \mathrm{i}$ in all cases $p>0.05$ )

In June, when pennate diatoms, cryptomonads, chlorophytes, and prasinophytes were abundant (Fig. 4), there was a significant effect of grazer density on the phytoplankton assemblage over both weeks of the experiment, but this effect varied among pools (Table 8 ). In the first week, we detected an effect of grazer density in 1 pool (Pool 3) where the abundance of pennate diatoms, cryptomonads and chlorophytes decreased in treatments with reduced grazer densities (i.e. the treatments where grazers were not manipulated, see 'Efficacy of manipula-

Table 6. F-values of analyses of variance of the density of micrograzers in the different treatments in the end of the experiments in November 1992, and June and August 1993. Factors are Grazer Density (G), Nutrient Concentration (N) and Pool (P). Comparisons show the results from Student-Newman-Keuls comparisons of treatment means. [Go = treatments with natural density of grazers (pooled GoNo and GoN + ); $\mathrm{G}-=$ treatments with reduced density of grazers (pooled $\mathrm{G}-\mathrm{No}$ and $\mathrm{G}-\mathrm{N}+$ ); $\mathrm{N}+=$ treatments with enriched nutrient concentrations (pooled GoN + and $G-N+$ ); No = treatments with natural nutrient concentrations (pooled

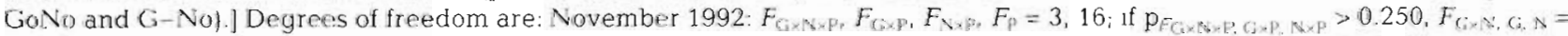

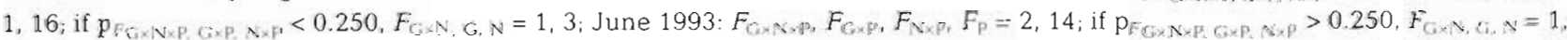

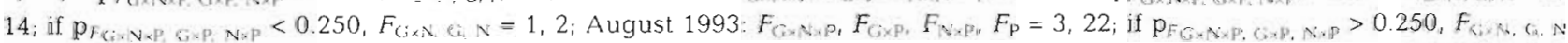
$=1,22 ;$ if $p_{F G \times N \times P, G \times P, N, p}<0.250, F_{G \wedge, G_{N}}=1,3$. For significant $F$-values $(p<0.05): \cdots p<0.001 ; \cdots p<0.01 ; " p<0.05$

\begin{tabular}{|c|c|c|c|c|c|c|c|c|c|}
\hline Date & Group & $G \times N \times P$ & $G \times P$ & $\mathrm{~N} \times \mathrm{P}$ & $G \times N$ & $\mathrm{P}$ & $\mathrm{G}$ & $N$ & Comparison \\
\hline Nov 1992 & $\begin{array}{l}\text { Planktonic } \\
\text { Benthic }\end{array}$ & $\begin{array}{l}0.55 \\
1.16\end{array}$ & $\begin{array}{l}1.89 \\
4.57^{\circ}\end{array}$ & $\begin{array}{c}1.84 \\
10.22 \cdots\end{array}$ & $\begin{array}{l}0.45 \\
0.12\end{array}$ & $\begin{array}{l}10.41 \cdots \\
41.59 \cdots\end{array}$ & $\begin{array}{l}1.79^{\mathrm{d}} \\
0.44^{\mathrm{d}}\end{array}$ & $\begin{array}{l}0.12^{d} \\
0.68^{\circ}\end{array}$ & Pool 3: Go $>\mathrm{G}-$ \\
\hline Jun 1993 & $\begin{array}{l}\text { Planktonic } \\
\text { Benthic }\end{array}$ & $\begin{array}{l}0.50 \\
0.14\end{array}$ & $\begin{array}{l}3.03 \\
1.83\end{array}$ & $\begin{array}{l}0.004 \\
0.07\end{array}$ & $\begin{array}{l}1.40 \\
0.33\end{array}$ & $\begin{array}{l}17.20 \cdots \\
11.88 \cdots\end{array}$ & $\begin{array}{l}0.79^{\mathrm{d}} \\
1.08\end{array}$ & $\begin{array}{l}1.12 \\
5.03\end{array}$ & $\overline{N_{+}}>\mathrm{No}_{0}$ \\
\hline Aug 1993 & $\begin{array}{l}\text { Planktonic } \\
\text { Benthic }\end{array}$ & $\begin{array}{l}0.29 \\
0.54\end{array}$ & $\begin{array}{l}2.06 \\
2.04\end{array}$ & $\begin{array}{l}0.09 \\
1.10\end{array}$ & $\begin{array}{l}0.23 \\
0.02\end{array}$ & $\begin{array}{c}43.67^{\cdots} \\
3.89^{\circ}\end{array}$ & $\begin{array}{l}1.00^{\mathrm{d}} \\
0.65^{\mathrm{a}}\end{array}$ & $\begin{array}{l}3.75 \\
2.16\end{array}$ & $\begin{array}{l}- \\
-\end{array}$ \\
\hline
\end{tabular}




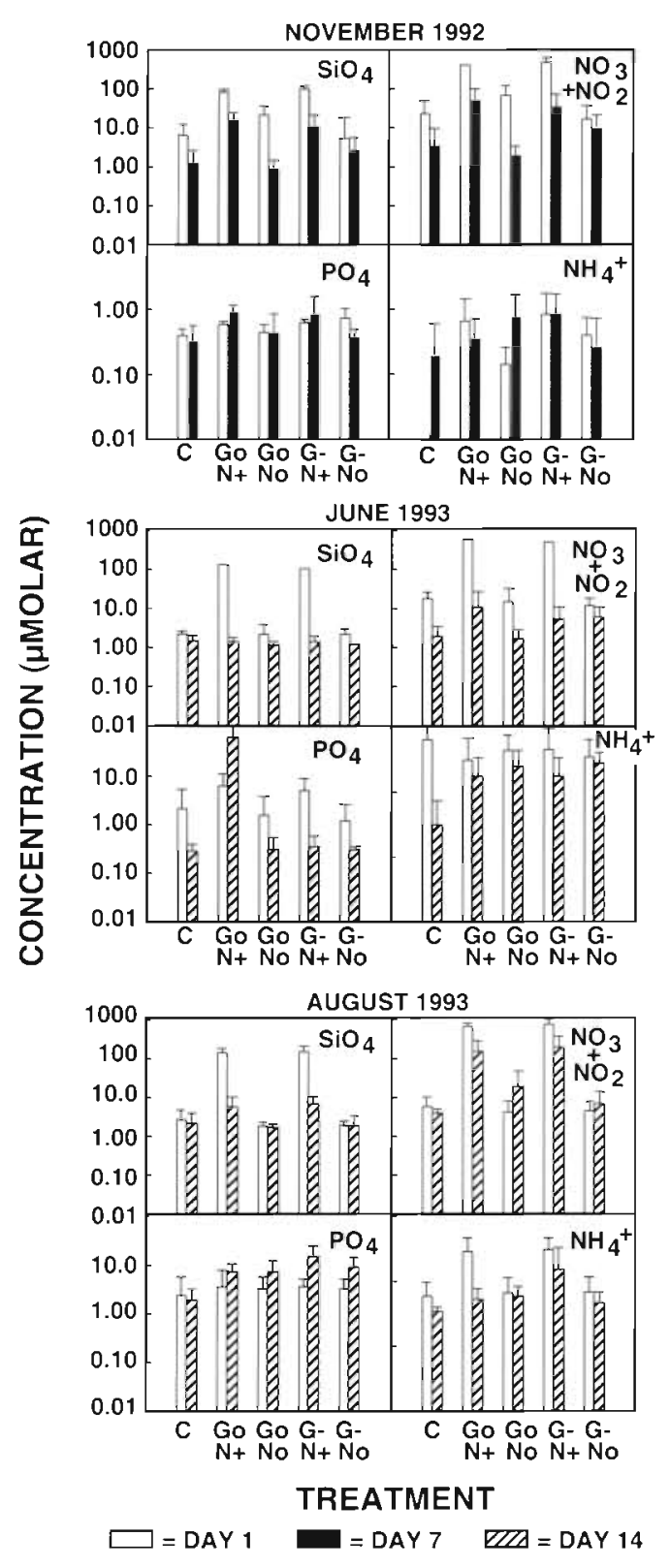

Fig. 2. Mean concentration of nutrients at the beginning and end of the experiments in November 1992 and in June and August 1993 in the different treatments. Treatment abbreviations as in Fig. 1 Error bars represent standard deviations (November and August: $n=4 ;$ June: $n=3$ )

tions') and increased in treatments with higher grazer densities. In the second week, we detected an effect of grazer density in 2 pools (Pools 3 and 5): the increase in abundance of pennate diatoms (Pool 3) and prasinophytes (Pool 5) was greater in treatments with reduced grazer densities (i.e. grazer removal treatments for Pool 5; treatments where grazers were not manipulated for Pool 3) than in treatments with higher grazer densities, while chlorophytes (Pool 5) showed the opposite trend.
In August, the same phytoplankton groups were present as in June, although they were less abundant (Fig. 5). In the first week of the experiment, there was a significant Grazer Density $\times$ Pool interaction, but the effect of Grazer Density was marginally non-significant in 2 pools (Pool $1 F_{4,7}=3.06, p=0.09 ;$ Pool $3 F_{3,8}=$ $3.30, p=0.08$ ). In the second week, there was a significant effect of grazer density in 1 pool (Pool 1) where the abundance of cryptomonads and chlorophytes decreased in the grazer removal treatments and increased in treatments where grazers were not manipulated (Table 9). There also was a significant effect of nutrients in the first week, when prasinophytes increased in 1 pool (Pool 1) and chlorophytes decreased in another pool (Pool 3) in the nutrientenriched treatments. In the treatments where nutrients were not manipulated, the abundance of prasinophytes remained low and that of chlorophytes showed a smaller decrease.

\section{DISCUSSION}

\section{Experimental manipulations}

The artifactual effects of the experimental enclosures on the response variable, change in the abundance of phytoplankton, and on both of the manipulated variables, density of micrograzers and concentration of nutrients, showed no consistent pattern among experiments, between weeks within experiments, or among pools. There were no significant effects of the unmanipulated enclosures (procedural controls) on the change in abundance of phytoplankton in experiments in November and June. In August, most changes were greater in the procedural controls than the natural controls, suggesting that the observed responses of phytoplankton to our manipulations were intensified in the enclosures. The experimental effect of planktonic micrograzers may have been damped, at least in some pools, in June and August. The concentration of silicate at the beginning of the experiment in November was greater in the enclosures in all pools, probably due to procedural contamination. Thus, the lack of a significant effect of nutrient enrichment on change in phytoplankton abundance in November may reflect insufficient differences in the initial concentration of nutrients between nutrient treatments.

There was no evidence of nutrient contamination of the pools (i.e. the natural controls) during the experiment through leakage from the nutrient-enriched enclosures. Nutrient concentrations were similar between the natural controls and the unmanipulated enclosures at the beginning of the experiments (except 
Table 7 F-values of analyses of variance of the concentrations of nutrients in the different treatments at the beginning (Beg) and end of the experiments in November 1992 and June and August 1993. The factors are Grazer Density (G), Nutrient Concentration $(\mathrm{N})$ and Pool $(\mathrm{P})$. Comparisons show the results from Student-Newman-Keuls comparisons of treatment means. $[\mathrm{Go}=$ treatments with natural density of grazers (pooled GoNo and GoN + ),$G-=$ treatments with reduced density of grazers (pooled $G-N o$ and $\mathrm{G}-\mathrm{N}+$ ); $\mathrm{N}+=$ treatments with enriched nutrient concentrations (pooled $\mathrm{GoN}+$ and $\mathrm{G}-\mathrm{N}+$ ); $N o=$ treatments with natural nutrient concentrations (pooled GoNo and $G-N o$.] Degrees of freedom for November 1992: $F_{G \times N \times p,} F_{G \times p}, F_{N \times p}, F_{p}=3,16 ;$

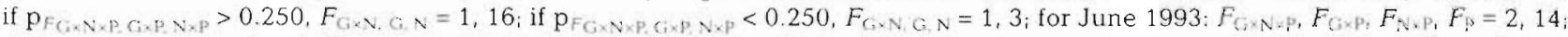

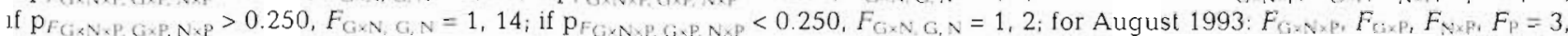

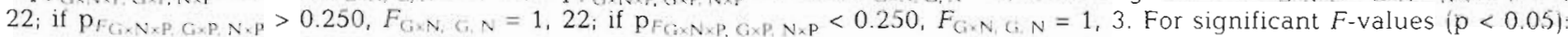
$\cdots p<0.001 ; \cdots p<0.01 ; \cdot p<0.05$

\begin{tabular}{|c|c|c|c|c|c|c|c|c|c|}
\hline Time & Nutrient & $G \times N \times P$ & $\mathrm{G} \times \mathrm{P}$ & $N \times P$ & $G \times N$ & $\mathrm{P}$ & $G$ & $N$ & Comparnson \\
\hline \multicolumn{10}{|c|}{ Nov 1992} \\
\hline \multirow[t]{4}{*}{ Beg } & Silicate & 2.91 & 1.68 & 1.95 & $4.78^{\circ}$ & 3.02 & $0.02^{\mathrm{u}}$ & $186.1 \cdots$ & $\mathrm{N}+>\mathrm{No}_{0}$ \\
\hline & Phosphate & 0.60 & 0.55 & 0.29 & $1.82^{\circ}$ & 0.99 & $3.50^{\circ}$ & $0.88^{d}$ & - \\
\hline & Nitrate & 2.46 & 1.96 & 1.02 & $1.85^{\mathrm{d}}$ & 1.34 & $1.56^{1}$ & $92.11 \cdots \mathrm{d}$ & $\mathrm{N}+>\mathrm{No}_{0}$ \\
\hline & Ammonium & 3.07 & 1.66 & 2.25 & $0.02^{\circ}$ & 1.00 & $0.60^{\circ}$ & $2.07^{d}$ & - \\
\hline \multirow[t]{4}{*}{ End } & Silicate & 0.55 & 0.45 & 0.04 & $1.06^{\mathrm{d}}$ & 0.14 & 0.16 & $5.79^{\circ}$ & $\mathrm{N}+>\mathrm{N}_{0}$ \\
\hline & Phosphate & 0.63 & 0.38 & 0.25 & 0.08 & 1.72 & 0.09 & 4.26 & $=$ \\
\hline & Nitrate & 1.03 & 0.15 & 0.60 & $0.27^{\circ}$ & 0.34 & $0.77^{\mathrm{d}}$ & $14.21^{\circ}$ & $\mathrm{N}+>\mathrm{No}$ \\
\hline & Ammonium & 0.60 & 1.68 & 1.91 & $4.69^{\circ}$ & $3.29^{\circ}$ & $0.00^{\mathrm{a}}$ & $0.11^{\text {d }}$ & Go, $\mathrm{G}_{-}: \mathrm{N}_{+}=\mathrm{No}_{0}$ \\
\hline \multicolumn{10}{|c|}{ Jun 1993} \\
\hline \multirow[t]{4}{*}{ Beg } & Silicate & 0.40 & 0.75 & 0.38 & 0.58 & 0.78 & 0.45 & $399.8^{\cdots}$ & $\mathrm{N}+>\mathrm{No}$ \\
\hline & Phosphate & 0.68 & 1.15 & $110.1 \cdots$ & 1.02 & $45.38 \cdots$ & 2.54 & $2.60^{\prime \prime}$ & Pools 1, 5: $\mathrm{N}_{+}>\mathrm{No}_{0}$ \\
\hline & Nitrate & 1.14 & 1.63 & 2.10 & 0.12 & 2.62 & $0.05^{\circ}$ & $146.0 \cdots \mathrm{d}$ & $\mathrm{N}+>\mathrm{No}$ \\
\hline & Ammonium & 0.26 & $4.41^{\circ}$ & $5.98^{\circ}$ & $23.75^{\bullet}$ & $41.18 \cdots$ & $0.06^{\circ}$ & $0.28^{\mathrm{a}}$ & Pool 1: $N+<N_{0}$ \\
\hline \multirow[t]{6}{*}{ End } & Silicate & $4.07^{\circ}$ & 2.76 & 1.60 & 0.00 & $4.08^{\circ}$ & $0.03^{\circ}$ & 1.7 .4 & All Pools: $N_{+}=N_{0}$ \\
\hline & Phosphate & $695.2 \cdots$ & $652.0^{\cdots}$ & $679.8 \cdots$ & $1.02^{d}$ & $629.7^{\cdots}$ & $1.06^{\mathrm{a}}$ & $1.12^{\circ}$ & Pool 1. N+>No \\
\hline & & & & & & & & & Pool 2: $N_{+}<N_{0}$ \\
\hline & & & & & & & & & Pool 1: Go > G- \\
\hline & Nitrate & 0.39 & 0.73 & 1.01 & 0.23 & 2.41 & 0.48 & 0.28 & - \\
\hline & Ammonium & 0.33 & 1.93 & 0.13 & 0.01 & $10.38 \cdots$ & $0.02^{d}$ & 1.84 & - \\
\hline \multicolumn{10}{|c|}{ Aug 1993} \\
\hline \multirow[t]{4}{*}{ Beg } & Silicate & 0.40 & 0.31 & $6.53 \cdots$ & 0.02 & $21.19^{\cdots}$ & 0.97 & $1031 \cdots \mathrm{c}$ & All Pools: $N_{+}>$No \\
\hline & Phosphate & 0.40 & 1.00 & $100.0^{\cdots}$ & 1.04 & $81.41 \cdots$ & 2.72 & $7.62^{\prime \prime}$ & All Pools: $\mathrm{N}_{+}>\mathrm{No}$ \\
\hline & Nitrate & 0.56 & 0.31 & $7.94^{\cdots}$ & 0.02 & $29.45 \cdots$ & 0.85 & $393.9 \cdots$ & All Pools: $\mathrm{N}+>\mathrm{No}$ \\
\hline & Ammonium & 0.35 & 2.26 & 1.58 & 0.01 & $18.23 \cdots$ & $0.00^{\circ}$ & $0.32^{\mathrm{c}}$ & - \\
\hline \multirow[t]{4}{*}{ End } & Silicate & 0.98 & 1.07 & $10.32 \cdots$ & 0.15 & $11.82 \cdots$ & 0.43 & $6.75^{\mathrm{d}}$ & Pools 1, 3, 5: $\mathrm{N}_{+}>\mathrm{No}$ \\
\hline & Phosphate & 0.53 & 0.43 & 0.55 & 2.03 & 2.69 & 0.65 & 1.33 & - \\
\hline & Nitrate & 0.62 & 0.45 & $4.21^{\circ}$ & 0.27 & 2.59 & 0.13 & $7.94^{\circ}$ & Pools $1,3,5: \mathrm{N}+>\mathrm{No}_{0}$ \\
\hline & Ammonium & 0.94 & 0.48 & 0.64 & 1.25 & 2.99 & 1.66 & 1.39 & - \\
\hline
\end{tabular}

for 1 pool in August where the concentration of phosphate was greater in the natural controls, although the difference was small). Furthermore, the concentrations of nutrients in the natural controls did not increase over the experimental period during any experiment.

In all experiments, the mean density of planktonic and benthic micrograzers in most pools was less in the treatments where grazers were reduced than in those where grazers were not manipulated. Also, the concentration of all manipulated nutrients at the beginning of each experiment was greater in the nutrientenriched treatments than in those that were not manipulated. Therefore, our experimental manipulations of grazer density and nutrient concentration generally were effective.

\section{Effects of grazer density on the abundance of phytoplankton}

Manipulation of grazer density affected the phytoplankton assemblage in June and August, and the effect varied among phytoplankton groups. Reduction in grazer density had a positive effect on prasinophytes, suggesting that this group is limited by grazing, especially in summer when grazers are abundant (Metaxas \& Scheibling 1994a). Conversely, reduction. of grazer density had a negative effect on cryptomonads and chlorophytes. Grazers may have beneficial effects for certain phytoplankton groups by increasing nutrient concentrations through excretion. For example, Vanni \& Findlay (1990) demonstrated that in- 
Fig. 3. Mean abundance of total phytoplankton and 4 phytoplankton groups in the different treatments in Pools (P) 1, 3, 4 and 5 at the beginning and end of the experiment in November 1992. Treatment abbreviations as in Fig. 1 Error bars represent standard deviations $(n=2)$
TOTAL PHYTOPLANKTON

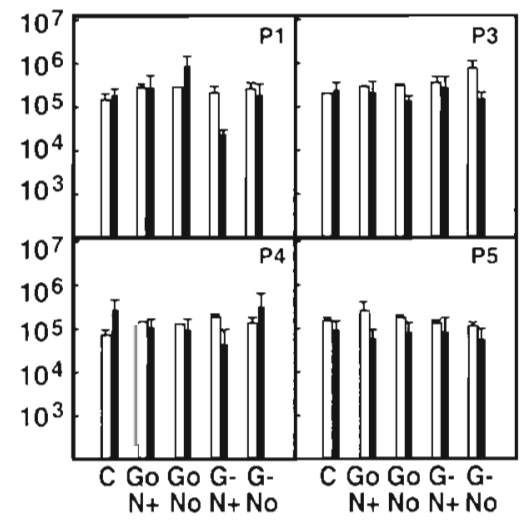

NOVEMBER 1992
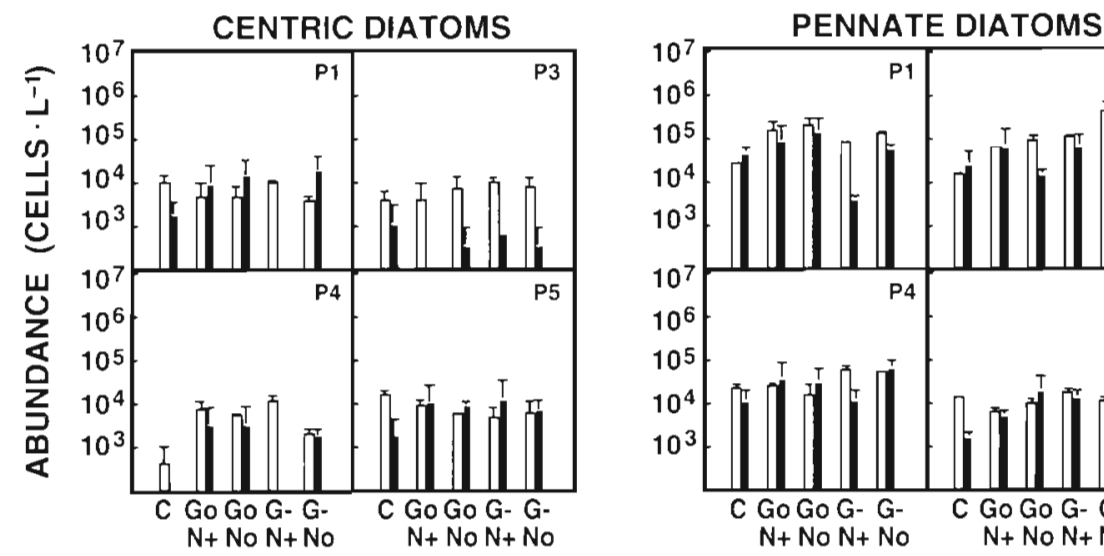

CRYPTOMONADS
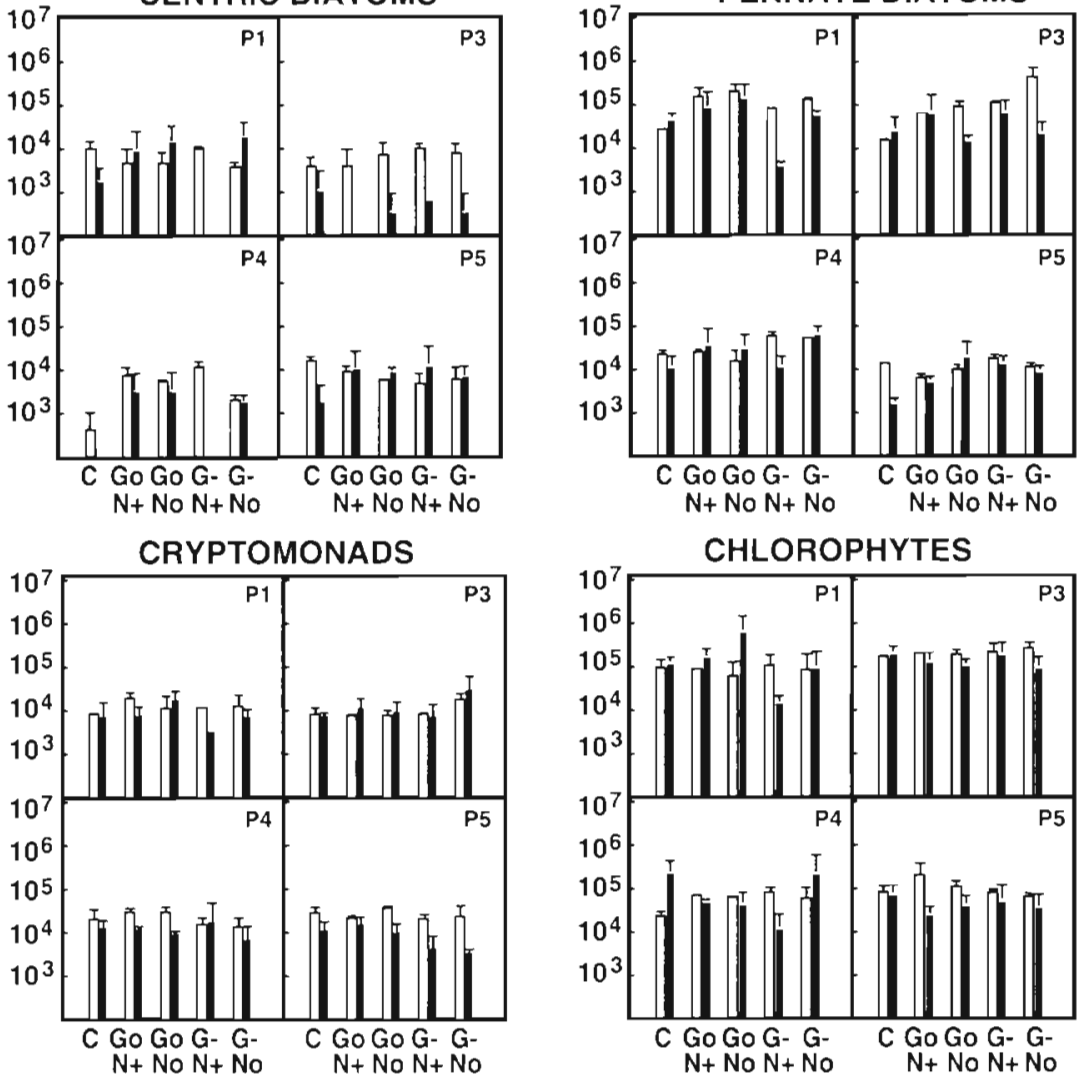

CHLOROPHYTES

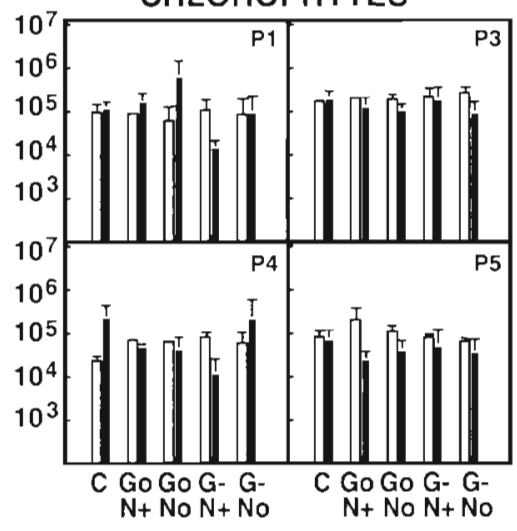

TREATMENT creased excretion by herbivorous fish resulted in increased abundance of nutrient-limited phytoplankton. Grazers also may enhance the abundance of some phytoplankton groups by selectively feeding on their potential competitors (e.g. when grazers were reduced in Pool 5 in June, prasinophytes increased as chlorophytes decreased). A reversal in the effect of grazers on pennate diatoms in 1 pool (Pool 3) during the experiment in June also may be related to competitive interactions. Reduction of grazers had a negative effect on all phytoplankters in the first week and a positive effect on pennates in the second, suggest- ing that pennates increased more rapidly than their competitors. The importance of grazers in influencing the phytoplankton assemblage was greatest in summer, a period of low ambient nutrient concentrations (Metaxas \& Scheibling 1996) and potentially increased competition for nutrients. Other studies also have shown that a reduction in grazer density can have a negative effect on the abundance of some phytoplankton groups but not others, thereby changing phytoplankton community structure (Lynch \& Shapiro 1981, Vanni 1987, Vanni \& Temte 1990, Rosemond et al. 1993). 


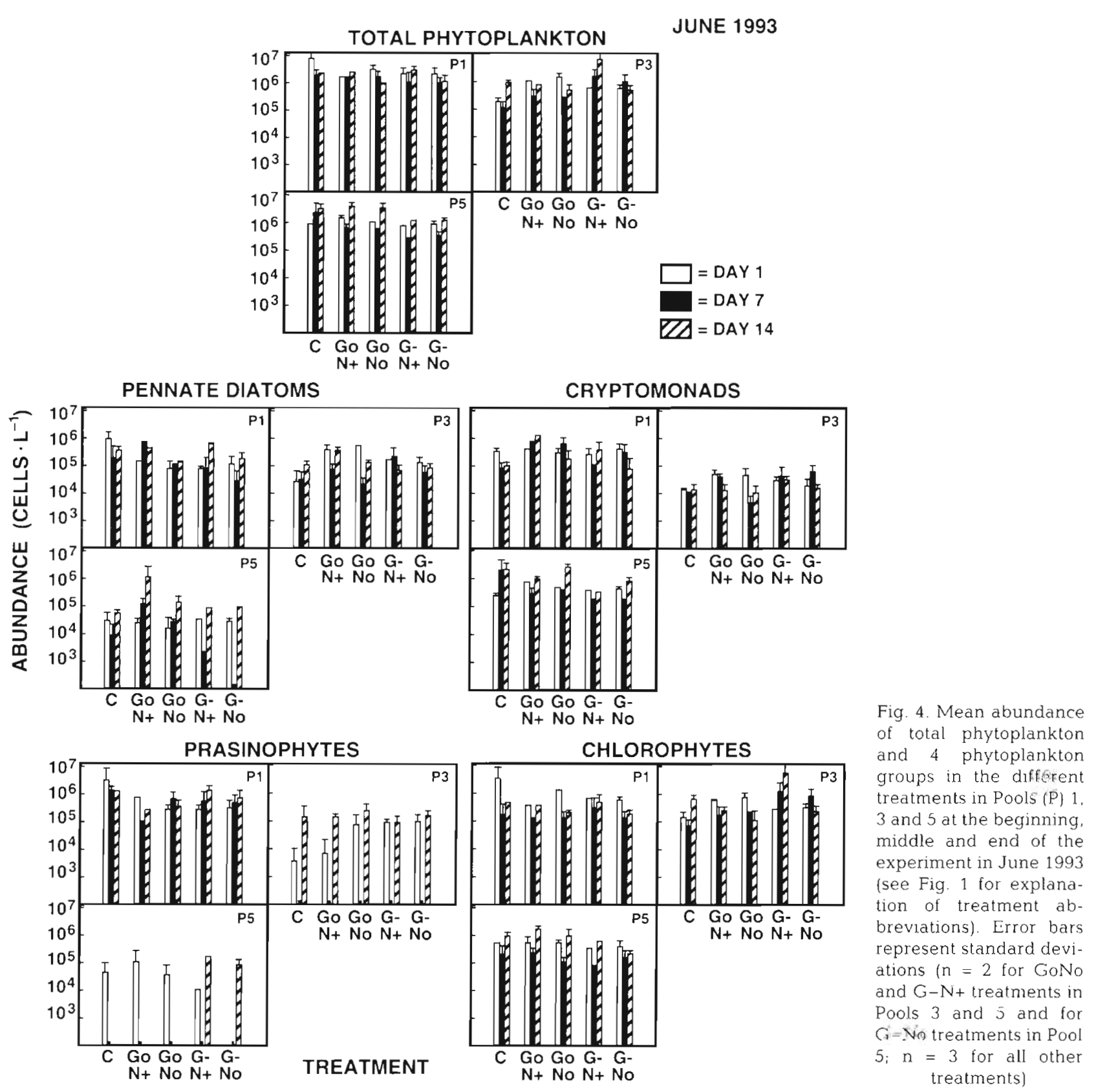

Effects of nutrient concentration on the abundance of phytoplankton

Nutrient enrichment affected the phytoplankton assemblage in August only, and the effect varied among phytoplankton groups. Previous studies in freshwater and marine systems have shown also that nutrient regulation of phytoplankton assemblages is more important in summer than in spring or fall (Vanni \& Temte 1990, Kivi et al. 1993). In August, nutrient enrichment had a positive effect on prasinophytes in 1 pool, where nutrient levels before enrichment $(<2 \mu \mathrm{M}$ for nitrate and silicate,$<1 \mu \mathrm{M}$ for ammo- nium, and < $0.5 \mu \mathrm{m}$ for phosphate) may have been limiting (Dortch 1990, Sieracki et al. 1993, Weeks et al. 1993a, b), and a negative effect on chlorophytes in another pool. Experimental studies in lakes also have shown different effects of nutrient enrichment on different phytoplankton species (Lynch \& Shapiro 1981. Vanni 1987). Because species have different nutrient requirements, the composition of a phytoplankton assemblage may be determined by the ratio of available macronutrients (Tilman et al. 1982). Thus, certain species may only co-exist at particular nutrient ratios and outcompete one another as the ratios change (Tilman 1977). 
Table 8. F-values of multivariate (MANOVA, Wilk's $\lambda$ ) and univariate (ANOVA) analyses of variance of percentage change in abundance of different phytoplankton groups (Pe: pennate diatoms; Cr cryptomonads; Pr: prasinophytes; Ch: chlorophytes) in the different treatments in the first ( 1 to $7 \mathrm{~d}$ ) and second week ( 8 to $14 \mathrm{~d}$ ) of the experiment in June 1993. The factors are Grazer Density (G), Nulnent Concentration (N) and Pool (P). The first line for each period shows the results of MANOVA for all pools followed by results of MANOVA for each Pool. Where there was a significant $N$ or $G$ effect for a Pool, results of MANOVA are followed by results of ANOVA for each phytoplankton group. Degrees of freedom are shown in parentheses. For significant F-values $(p<0.05): \cdots p<0.001 ; \cdots p<0.01 ; " p<0.05$

\begin{tabular}{|c|c|c|c|c|c|c|c|c|c|}
\hline Period (d) & Pool & Group & $N$ & G & $G \times N$ & $\mathrm{P}$ & $\mathrm{N} \times \mathrm{P}$ & $\mathrm{G} \times \mathrm{P}$ & $\mathrm{G} \times \mathrm{N} \times \mathrm{P}$ \\
\hline \multirow[t]{8}{*}{$1-7$} & All & All & $0.27_{[4,16]}$ & $3.46^{\circ}(4,16)$ & $1.46_{\mid 4.16)}$ & $2.89^{\circ}{ }_{(8,32)}$ & $0.91_{\{8,32\}}$ & $2.36^{\circ}(8,32)$ & $1.51_{\{8,32\}}$ \\
\hline & 1 & All & - & $2.94_{(4,3)}$ & & & & & \\
\hline & 3 & All & - & $13.67^{*}{ }_{14,7}$ & & & & & \\
\hline & & $\mathrm{Pe}$ & - & $9.58^{\circ}(1,10)$ & & & & & \\
\hline & & $\mathrm{Cr}$ & - & $5.66^{\circ}(1,10)$ & & & & & \\
\hline & & $\operatorname{Pr}$ & - & $3.37,1,101$ & & & & & \\
\hline & & $\mathrm{Ch}$ & - & $14.72{ }^{*}$ & & & & & \\
\hline & 5 & All & -- & $2.26_{\{4.6\}}$ & & & & & \\
\hline \multirow[t]{12}{*}{$8-14$} & A.ll & All & $1.99_{(4,16)}$ & $4.91{ }^{\prime 4,16 \mid}$ & $0.61_{(4,16)}$ & $11.27^{\cdots}{ }_{(8,32)}$ & $1.53_{\mid 8,321}$ & $5.84{ }^{\cdots}{ }_{\{8,32\}}$ & $0.95_{(8,32)}$ \\
\hline & 1 & All & - & $0.57_{(4,3)}$ & & & & & \\
\hline & 3 & All & - & $5.69^{\circ}(4,7)$ & & & & & \\
\hline & & $\mathrm{Pe}$ & - & $26.49 \cdots(1,10)$ & & & & & \\
\hline & & $\mathrm{Cr}$ & - & $0.12_{(1,10)}$ & & & & & \\
\hline & & $\mathrm{Pr}$ & - & $1.45_{11,10)}$ & & & & & \\
\hline & & $\mathrm{Ch}$ & - & $0.04_{11.10)}$ & & & & & \\
\hline & 5 & All & - & $341 \cdots_{\mid 4,6)}$ & & & & & \\
\hline & & $\mathrm{Pe}$ & - & $3.21_{|1.9|}$ & & & & & \\
\hline & & $\mathrm{Cr}$ & - & $3.01_{\mid 1,9)}$ & & & & & \\
\hline & & $\operatorname{Pr}$ & - & $717.1 \cdots \cdots_{11.9}$ & & & & & \\
\hline & & $\mathrm{Ch}$ & - & $10.29^{\circ}$ & & & & & \\
\hline
\end{tabular}

\section{Relative importance of grazers and nutrients in regulating of phytoplankton assemblages in tidepools}

The phytoplankton assemblage responded to changes in both top-down (grazer density) and bottomup (nutrient concentration) factors; however, the relative importance of these 2 types of factors varied among phytoplankton groups, tidepools and experiments. In November, neither of the 2 factors had an effect on the phytoplankton assemblage; there was little or no phytoplankton growth and the pools were frozen by the end of the experiment. In June and August, the assemblage responded more frequently to manipulation of grazer density than nutrient concentration, in terms of both the number of phytoplankton groups and the number of pools. In other marine and freshwater systems, the relative importance of nutrients and grazing in regulating phytoplankton community structure also varies with seasonal changes in the dominant phytoplankton and zooplankton (Vanni \& Temte 1990, Kivi et al. 1993).

Under simultaneous top-down and bottom-up regulation, an interactive effect of grazing and nutrient availability on the phytoplankton assemblage is expected, such that the greatest change in abundance should be observed in the treatment where grazers were removed and nutrients were enriched. Because we did not detect any significant 2-way (Grazer Density $\times$ Nutrient Concentration) or 3-way (Grazer Density $\times$ Nutrient Concentration $\times$ Pool) interactions, simultaneous regulation probably did not occur in our system. Contrary to our results, Rosemond et al. (1993) showed strong simultaneous control on chlorophyll a in experimental manipulations in streams: nutrient enrichment had a stronger effect in the absence of grazers than in their presence.

There was large among-pool variability in the response of the phytoplankton assemblage to our grazer manipulations, as indicated by the significant interactions with Pool. Our results suggest that these differences among pools are related to differences in the dominant grazers. Among the pools with a significant effect of grazer density, planktonic-feeding copepods (Eurytemora affinis) were dominant in Pool $3\left(\sim 1000\right.$ ind. $\left.\mathrm{l}^{-1}\right)$, whereas benthic-feeding nematodes (presumably feeding on phytoplankton that have sunk to the bottom) were dominant in Pool $5\left(\sim 100\right.$ ind. $\left.\mathrm{l}^{-1}\right)$ in June, and benthic-feeding harpacticoid copepods were dominant in Pool 1 ( 40 ind. $\mathrm{l}^{-1}$ ) in August. In other pools, where different grazers were just as abundant, we did not detect significant effects on the phytoplankton assemblage. For 


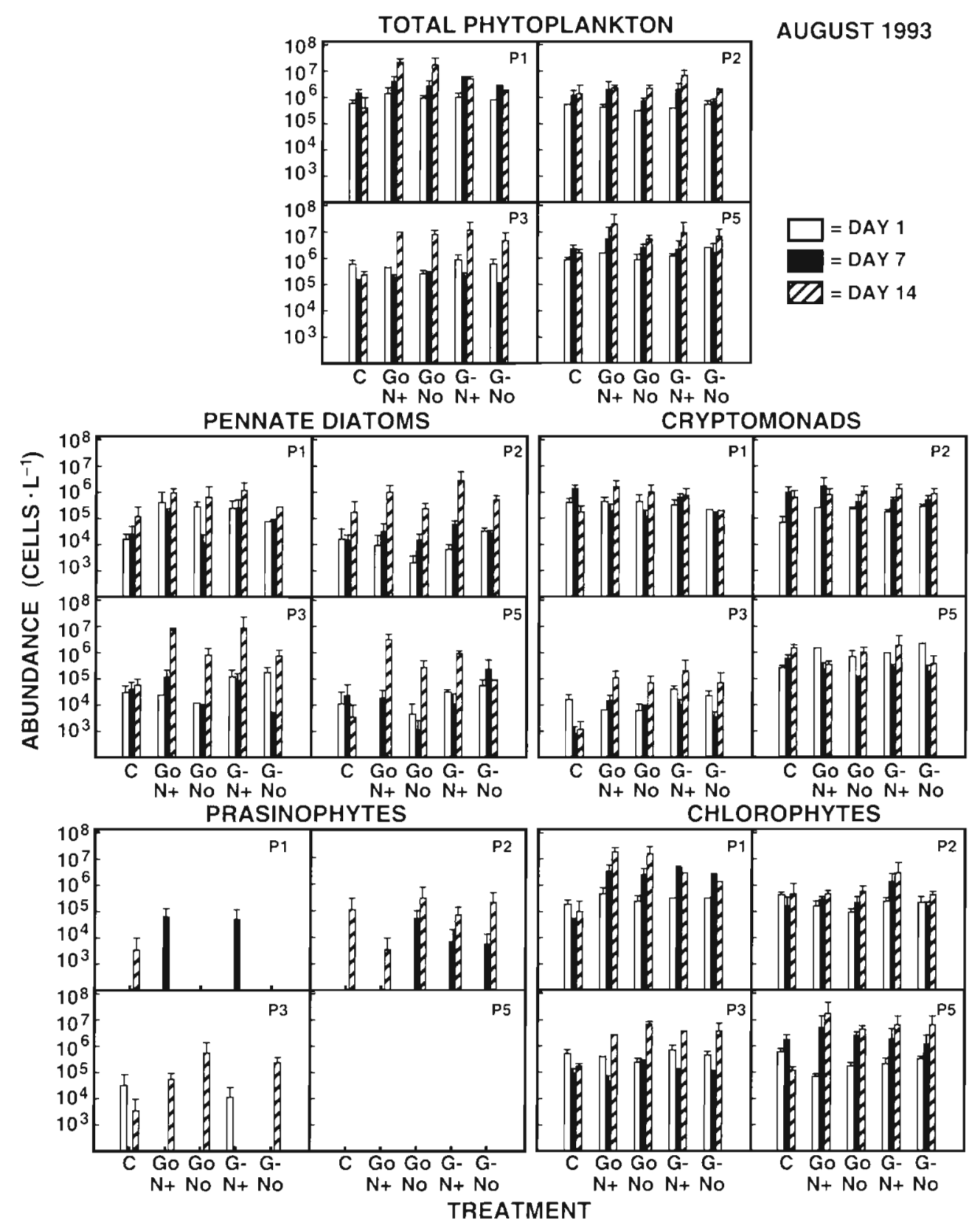

Fig. 5. Mean abundance of total phytoplankton and 4 phytoplankton groups in the different treatments in Pools (P) 1, 2, 3 and 5 at the beginning, middle and end of the experiment in August 1993. Treatment abbreviations as in Fig. 1. Error bars represent standard deviations $(n=2$ for GoN+treatments in Pool 3, GoNo and G-N+treatments in Pools 3 and 5, G-No treatments in Pools 2 and $3 ; n=3$ for all other treatments)

example, there was no effect of grazer density in Pool 1 in June or in Pool 5 in August when these pools were dominated by planktonic-feeding rotifers at densities of 500 to 1000 ind. $\mathrm{l}^{-1}$. Our results also show that grazers which can potentially regulate the phytoplankton assemblage must be sufficiently abundant to do so. For example, there was no effect of grazer density in Pool 3 in August when the density of the dominant grazer, E. affinis, was -40 ind $~^{-1}$ (cf. Pool 3 in June).
In earlier studies, we have shown that the main source of spatial variability in phytoplankton assemblages, and in the factors that potentially regulate these assemblages, is among tidepools within intertidal zones (Metaxas \& Scheibling 1994a, b, 1996, Metaxas et al. 1994). On the basis of these descriptive studies, we proposed that the nutrient regime and the grazer field are the main factors that regulate the resident phytoplankton assemblages in tidepools and the 
Table 9. F-values of multivariate (MANOVA. Wilk's $\lambda$ ) and univariate (ANOVA) analyses of variance of percentage change in abundance of different phytoplankton groups (Pe: pennate diatoms; Cr: cryptomonads, Pr: prasinophytes; Ch: chlorophytes) in the different treatments in the first ( 1 to $7 \mathrm{~d}$ ) and second week ( 8 to $14 \mathrm{~d}$ ) of the experiment in August 1993. The factors are Grazer Density (G), Nutrient Concentration (N) and pool (P). The first line for each period shows the results of MANOVA for all pools followed by results of MANOVA for each Pool. Where there was a signuficant $N$ or $G$ effect for a Pool, results of MANOVA are followed by results of ANOVA for each phytoplankton group. Degrees of freedom are shown in parentheses. For significant $F$-values $(p<0.05): \cdots p<0.001 ; \cdots p<0.01 ; \cdot p<0.05$

\begin{tabular}{|c|c|c|c|c|c|c|c|c|c|}
\hline Period (d) & Pool & Group & $N$ & $\mathrm{G}$ & $G \times N$ & $\mathrm{P}$ & $\mathrm{N} \times \mathrm{P}$ & $G \times P$ & $G \times N \times P$ \\
\hline \multirow[t]{5}{*}{$1-7$} & All & All & $1.40_{(4,28)}$ & $1.31_{(4,28)}$ & $0.51_{1, i}$ & $11.64{ }^{\prime} \cdots_{(12,74)}$ & $2.67^{\cdots}$ & $2.45^{\cdots}{ }_{|12,74|}$ & $1.62_{(12,74)}$ \\
\hline & 1 & $\begin{array}{l}\text { All } \\
\mathrm{Pe} \\
\mathrm{Cr} \\
\mathrm{Pr} \\
\mathrm{Ch}\end{array}$ & $\begin{array}{l}5.80^{\circ} \\
2.52,11,10\} \\
0.31_{\{1,10\}} \\
\left.23.94^{\cdots} \cdots 1,10\right\} \\
0.67_{\{1,10\}}\end{array}$ & $\begin{array}{l}3.06\{4,7\} \\
- \\
- \\
- \\
-\end{array}$ & & & & & \\
\hline & 2 & All & $3.38_{\{4,7)}$ & $0.14_{(4,7)}$ & & & & & \\
\hline & 3 & $\begin{array}{l}\mathrm{All} \\
\mathrm{Pe} \\
\mathrm{Cr} \\
\mathrm{Pr} \\
\mathrm{Ch}\end{array}$ & $\begin{array}{l}4.19^{\circ}(4,7) \\
2.18_{(1,10)} \\
0.11_{\{1,10\}} \\
2.50_{(1,10\}} \\
6.12^{\circ}{ }_{(1,10)}\end{array}$ & $\begin{array}{l}3.30_{\{3,8\}} \\
- \\
- \\
- \\
-\end{array}$ & & & & & \\
\hline & 5 & All & $0.45_{(3,7)}$ & $1.89_{\{3,7\}}$ & & & & & \\
\hline \multirow[t]{5}{*}{$8-14$} & All & All & $0.43_{14.28}$ & $3.11^{\circ}{ }_{(4.28)}$ & $0.57: \ldots$ & $7.96^{\cdots} \cdots_{(12,74)}$ & $1.15_{(12,74)}$ & $2.41^{\circ}(12,74\}$ & $0.61_{(12,34)}$ \\
\hline & 1 & $\begin{array}{l}\text { All } \\
\mathrm{Pe} \\
\mathrm{Cr} \\
\mathrm{Pr} \\
\mathrm{Ch}\end{array}$ & $\begin{array}{l}- \\
- \\
- \\
- \\
-\end{array}$ & $\begin{array}{c}8.31 \cdots_{147)} \\
0.02(1,10) \\
13.25 \cdots_{(1.10)} \\
0.26_{(1.10)} \\
40.46 \cdots^{\prime 1,10)}\end{array}$ & & & & & \\
\hline & 2 & All & - & $0.61_{(4,7)}$ & & & & & \\
\hline & 3 & All & - & $0.8 \hat{\sigma}_{14,7)}$ & & & & & \\
\hline & 5 & All & - & $0.36_{\{4,6\}}$ & & & & & \\
\hline
\end{tabular}

relative importance of these factors varies at the scale of the individual pool (Metaxas \& Scheibling 1996). Our experimental results support this hypothesis, but show that grazing may be more important than nutrient availability in regulating phytoplankton in tidepools. Our experiments were conducted in high and splash pools where single-taxon populations of planktonic and benthic micrograzers persist interannually (Metaxas \& Scheibling 1994a). The composition of phytoplankton assemblages in the pools appears to be regulated by these large populations of micrograzers that are specific to individual pools.

Acknowledgements. We thank Brian Dixon, Heather Hunt, and Don Webb for assisting in the field work and Pierre Clement (Marne Chemistry Division of the Department of Fisheries and Oceans at the Bedford Institute of Oceanography in Dartmouth, Nova Scotia, Canada) for analyzing the nutrient samples for nitrate+nitrite, phosphate and silicate. Drs A. R. O. Chapman, S. D. Gaines, B. G. Hatcher, S. Walde and D. G. Webb critically read earlier drafts of the manuscript. In particular, we thank Don Webb for insightful discussions throughout the study. A.M. was supported by a Postgraduate Scholarship from the 'Alexander S. Onassis' Public Benefit Foundation (Athens, Greece) and scholarships from the
Faculty of Graduate Studies, Dalhousie University. The research was funded by a Research Grant from the Natural Sciences and Engineering Research Council Research Grant to R.E.S

\section{LITERATURE CITED}

Barnes RD (1980) Invertebrate zoology, 2nd edn. Saunders College, Philadelphia

Bosman A., Du Toit JT, Hockey PAR, Branch GM (1986) A field experiment demonstrating the influence of seabird guano on intertidal primary production. Estuar Coast Shelf Sci 23:283-294

Bosman AL, Hockey PAR (1986) Seabird guano as a determinant of rocky intertidal community structure. Mar Ecol Prog Ser 32:247-257

Bosman AL, Hockey PAR (1988) The influence of seabird guano on the biological structure of rocky intertidal communities on islands of the west coast of southern Africa. S Afr J Mar Sci 7:61-68

Brinkhurst RO, Linkletter LE, Lord EI, Connors SA, Dadswell M. (1976) A preliminary guide to the littoral and sublittoral invertebrates of Passamaquoddy Bay. Identification Center, Department of the Environment, Fisheries and Marine Service, Biological Station, St. Andrews, New Brunswick 
Carpenter SR, Kitchell JF (1984) Plankton community structure and limnetic primary production. Am Nat 124: $159-172$

Chrétiennot-Dinet MJ (1990) Atlas du phytoplanctón marn. Vol 3: chlorarachniophycées, chlorophycees, chrysophycées, cryptophycées, euglénophycées, eustigmatophycées, prasinophycées, prymnésiophycées, rhodophycées, tribophycées. Editions du CNRS, Paris

Connell JH (1972) Community interactions on marine rocky intertidal shores. A Rev Ecol Syst 3:169-192

Connell JH (1983) On the prevalence and relative importance of interspecific competition: evidence from field experiments. Am Nat 122:661-696

Cupp EE (1943) Marine plankton diatoms of the west coast of North America. University of California Press, Berkeley

Dayton PK (1971) Competition, disturbance, and community organization: the provision and subsequent utilization of space in a rocky intertidal community. Ecol Monogr 41. $351-389$

Dayton PK (1984) Processes structuring some marine communities: are they general? In: Strong DR Jr, Simberloff D, Abele LG, Thistle AB (eds) Ecological communities: conceptual issues and the evidence. Princeton University Press, Princeton, p 181-197

Dortch Q (1990) The interaction between ammonium and nitrate uptake in phytoplankton. Mar Ecol Prog Ser 61. $183-201$

Ganning B, Wulff F (1969) The effects of bird droppings on chemical and biological dynamics in brackısh water rockpools. Oikos 20:274-286

Gardner GA, Szabo I (1982) British Columbia pelagic marine copepoda: an identification manual and annotated bibliography. Can Spec Publ Fish Aquat Sci 62

Gervais F (1991) Which factors controlled seasonal and spatial distrubution of phytoplankton species in Schlachtensee (Berlin, F.R.G.) 1987? Arch Hydrobiol 121:43-65

Hansson LA (1992) The role of food chain composition and nutrient availability in shaping algal biomass development. Ecology 73:241-247

Harrison PJ, Fulton JD, Taylor FJR, Parsons TR (1983) Review of the biological oceanography of the Strait of Georgia: pelagic environment. Can J Fish Aquat Sci 40:1064-1094

Harrison PJ, Waters RE, Taylor FJR (1980) A broad spectrum artificial seawater medium for coastal and open ocean phytoplankton. J Phycol 16:28-35

Hecky RE, Kilham P (1988) Nutrient limitation of phytoplankton in freshwater and marine environments: a review of recent evidence on the effects of enrichment. Limnol Oceanogr 33:796-822

Hendey NI (1964) An introductory account of the smaller algae of British coastal waters. Part V: Baccilariophyceae (diatoms). Ministry of Agriculture, Fisheries and Food, Fisheries Investigations Series IV, HMSO, London

Hunter MD, Price PW (1992) Playing chutes and ladders: heterogeneity and the relative roles of bottom-up and topdown forces in natural communities. Ecology $73: 724-732$

Jemakoff $P$ (1985) An experimental evaluation of the influence of barnacles, crevices and seasonal patterns of grazing on algal diversity and cover in an intertidal barnacle zone. J Exp Mar Biol Ecol 88:287-302

Kerfoot WC, Sih A (1987) Predation: direct and indirect effects on aquatic communities. University Press of New England, Hanover

Kivi K, Kaitala S, Kuosa H, Kuparinen J, Leskinen E, Lignell R, Marcussen B, Tamminen T (1993) Nutrient limitation and grazing control of the Baltic plankton community during annual succession. Limnol Oceanogr 38:893-905
Lubchenco J, Menge: BA (1978) Communty development and porsistence in a low rocky intertidal zone. Ecol Monogr 48 $6 \overline{7}-94$

Lund JWG, Kiplıng C, Le Cren ED (1958) The inverted microscope method of estimating algal numbers and the statist1cal basis of estimations by counting. Hydrobiologia 11 $143-170$

Lynch M, Shapiro J (1981) Predation, enrichment, and phytoplankton community structure. Limnol Oceanogr 26 86-102

McQueen DJ, Johannes MRS, Post JR, Stewart TJ, Lean DRS (1989) Bottom-up and top-down impacts on freshwater pelagic community structure. Ecol Monogr 59 289-309

McQueen DJ, Post JR, Mills EL (1986) Trophic relationships in freshwater pelagic ecosystems. Can J Fish Aquat Sci 43 $1571-1581$

Menge BA (1976) Organization of the New England rocky intertidal community: role of predation, competition, and environmental heterogeneity. Ecol Monogr 46:355-393

Menge BA (1992) Community regulation: under what conditions are bottom-up factors important on rocky shores? Ecology 73:755-765

Metaxas A, Hunt HL, Scheibling RE (1994) Spatial and temporal variability of macrobenthic assernblages in tidepools on a rocky shore in Nova Scotia, Canada. Mar Ecol Prog Ser 105:89-103

Metaxas A, Scheibling RE (1994a) Spatial and temporal variability of tidepool hyperbenthos on a rock: shore in Nova Scotia, Canada. Mar Ecol Prog Ser 108:17j. 184

Metaxas A, Scheibling RE (1994b) Changes in phytoplankton abundance in tidepools over the period of tidal isolation. Bot Mar 37:301-314

Metaxas A, Scheibling RE (1996) Spatial heterogeneity of phytoplankton assemblages in tidepools: effects of abiotic and biotic factors. Mar Ecol Prog Ser 130:179 199

Morales CE, Bedo A, Harris RP, Tranter PRC; (1991) Grazing of copepod assemblages in the north-east Atlantic: the importance of the small size fraction. J Plankton Res 13 $455-472$

Paine RT (1966) Food web complexity and species diversity. Am Nat 100:65-75

Parsons TR, Maita Y, Lalli CM (1984) A manual of chemical and biological methods for seawater analysis. Pergamon Press, Oxford

Petraitis PS (1983) Grazing patterns of the periwinkle and their effect on sessile intertidal organisms. Ecology 64: $522-533$

Petraitis PS (1987) Factors organizing rocky intertidal communities of New England: herbivory and predation in sheltered bays. J Exp Mar Biol Ecol 109:117-136

Reid PC, Lancelot C, Gieskes WWC, Hagmeier E; Weichart G (1990) Phytoplankton of the North Sea and its dynamics: a review. Neth J Sea Res 26:295-331

Ricard M (1987) Atlas du phytoplanctón marin, Vol 2: Diatomaphycées. Editions du CNRS, Paris

Rosemond AD, Mulholland PJ, Elwood JW (1993). Top-down and bottom-up control of stream periphyton: effects of nutrients and herbivores. Ecology 74:1264-1280

Sieracki ME, Verity PG. Stoecker DK (1993) Plankton community response to sequential silicate and nitrate depletion during the 1989 North Atlantic sprng bloom. Deep Sea Res 40:213-225

Smith RI (1964) Keys to marine invertebrates of the Woods Hole region. Contribution No. 11, Systematics-Ecology Program, Marine Biological Laboratory. Woods Hole, MA. Spaulding Co, Boston 
Sournia A (1986) Atlas du phytoplanctón marin, Vol 1 cyanophycées, dictyophycées, dinophycées, raphidophycées. Editions du CNRS, Paris

Sousa WP (1984) Intertidal mosaics: patch size, propagule availability, and spatially variable patterns of succession. Ecology 65:1918-1935

Threlkeld ST (1988) Planktivory and planktivore biomass effects on zooplankton, phytoplankton, and the trophic cascade. Limnol Oceanogr 33:1362-1375

Tilman D (1977) Resource competition between planktonic algae: an experimental and theoretical approach. Ecology 58:338-348

Tilman D, Kilham SS, Kilham P (1982) Phytoplankton community ecology: the role of limiting nutrients. Anmu Rev Ecol Syst 13:349-372

Underwood AJ (1981) Techniques of analysis of variance in experimental biology and ecology. Oceanogr Mar Biol Annu Rev 19:513-605

Underwood AJ, Denley EJ (1984) Paradigms, explanations, and generalizations in models for the structure of intertidal communities on rocky shores. In: Strong DR Jr, Simberloff D, Abele LG, Thistle AB (eds) Ecological communities: conceptual issues and the evidence. Princeton University Press, Princeton, p 151-180

Vanni M (1987) Effects of nutrients and zooplankton size on the

This article was presented by $R$. N. Hughes, Bangor, United Kingdom structure of a phytoplankton community. Ecology 68:624-635

Vanni M, Findlay DL (1990) Trophic cascades and phytoplankton community structure. Ecology 71:921-937

Vanni M. Temte J (1990) Seasonal patterns of grazing and nutrient limitation of phytoplankton in a eutrophic lake. Limnol Oceanogr 35:697-709

Wassman P (1991) Dynamics of primary production and sedimentation in shallow fjords and polls of western Norway. Oceanogr Mar Biol Annu Rev 29:87-154

Weeks AR, Fasham MJR, Aiken J, Harbour DS, Read JF, Bellan I (1993a) The spatial and temporal development of the spring bloom during the JGOFS North Atlantic bloom experiment, 1989. J Mar Biol Ass UK 73:253-282

Weeks AR, Conte MH, Harris RP, Bedo A, Bellan I, Burkill PH, Edwards ES, Harbour DS, Kennedy H, Llewellyn C, Mantoura RFC, Morales CE, Pomroy AJ, Turley CM (1993b) The physical and chemical environment and changes in community structure associated with bloom evolution: the Joint Global Flux Study North Atlantic bloom experiment. Deep Sea Res 40:347-368

Winer BJ (1971) Statistical principles in experimental design. McGraw-Hill, New York

Wootton JT (1991) Direct and indirect effects of nutrients on intertidal community structure: variable consequences of seabird guano. J Exp Mar Biol Ecol 151:139-1530

Manuscript first received: June 12, 1996

Revised version accepted: September 9, 1996 